\title{
Reaktorsystem zur Massenkultivation von pflanzlichen Zellkulturen bei niedrigem hydrodynamischem Stress
}

\author{
Max Hegglin, Jiří E. Prenosil* und John R. Bourne
}

A simple new method for efficient self-immobilization of plant cells has been developed based on the natural cell tendency to aggregate. By this method tight cell beads of up to several $\mathrm{mm}$ in diameter can be grown. - The cell lines of Coffea arabica and Nicotina tabacum growing in such beads were used in a specially designed expanded-bed reactor. A separate oxygenation vessel in the medium circulation loop was used to eliminate the shear stress caused by direct aeration. - High cell densities and an excellent growth rate of the aggregates in the reactor comparable to the best shake-flask experiments was achieved, however, the production of secondary metabolites (alkaloids) was very low. Therefore, the expanded-bed reactor can be employed advantageously for biomass production in a first stage of a plant cell reactor system.

\section{Einleitung}

Pflanzen synthetisieren eine Vielzahl für den Menschen nützlicher Substanzen. Noch heute enthält rund ein Viertel aller verschriebener Arzneimittel Wirkstoffe, die aus Pflanzen gewonnen werden. Seit einiger Zeit ist man imstande, Pflanzenzellen ähnlich wie die Mikroorganismen zu züchten.

Die Gewinnung pflanzlicher Inhaltsstoffe aus Zell- oder Organkulturen hätte gegenüber dem konventionellen Anbau beträchtliche Vorteile, z. B. die Unabhängigkeit vom Verbreitungsgebiet der Pflanzen oder von klimatischen Einflüssen. Besteht ein Bedarf an einem pflanzlichen Inhaltsstoff, so bietet sich die Produktion mittels Zellkulturen in Konkurrenz zur Gewinnung aus ganzen Pflanzen sowie auch zu dessen chemischer Synthese an. Zudem wären auch Kombinationsverfahren möglich, d.h. die Umwandlung von synthetischen Chemikalien durch Pflanzenzellen
(Biotransformation) oder durch Enzyme, die aus Pflanzen gewonnen werden. Eine weitere Möglichkeit bietet die Übertragung von entsprechenden Genen aus Pflanzen in einfacher $\mathrm{zu}$ handhabende Mikroorganismen.

Im Jahre 1983 führte Mitsui Ltd., Japan, mit der Produktion von Shikonin, einem Farbstoff und Pharmazeutikum (aus $\mathrm{Li}$ thospermum erythrorhizon), den ersten industriellen Prozess zur Gewinnung eines Produkts aus Zellkulturen ein. Randbedingungen, wie ein Produktpreis von 4500 \$/ $\mathrm{kg}$ bei einem Nachfrageüberschuss und ein Zelltrockengewichtsanteil an Shikonin von $14 \%$, welche die Realisierung begünstigten, werden von Payne et al. "II beschrieben.

Einem weiteren Durchbruch in der pflanzlichen Biotechnologie stehen einige wesentliche Eigenschaften der pflanzlichen Zellkulturen im Wege:

- langsames Wachstum;

- niedrige Produktionsrate;

- hohe Scherempfindlichkeit.

* Korrespondenz: Dr. J.E. Prenosil Laboratorium für Technische Chemie Eidgenössische Technische Hochschule Zürich ETH-Zentrum, Universitätstrasse 6 $\mathrm{CH}-8092$ Zürich

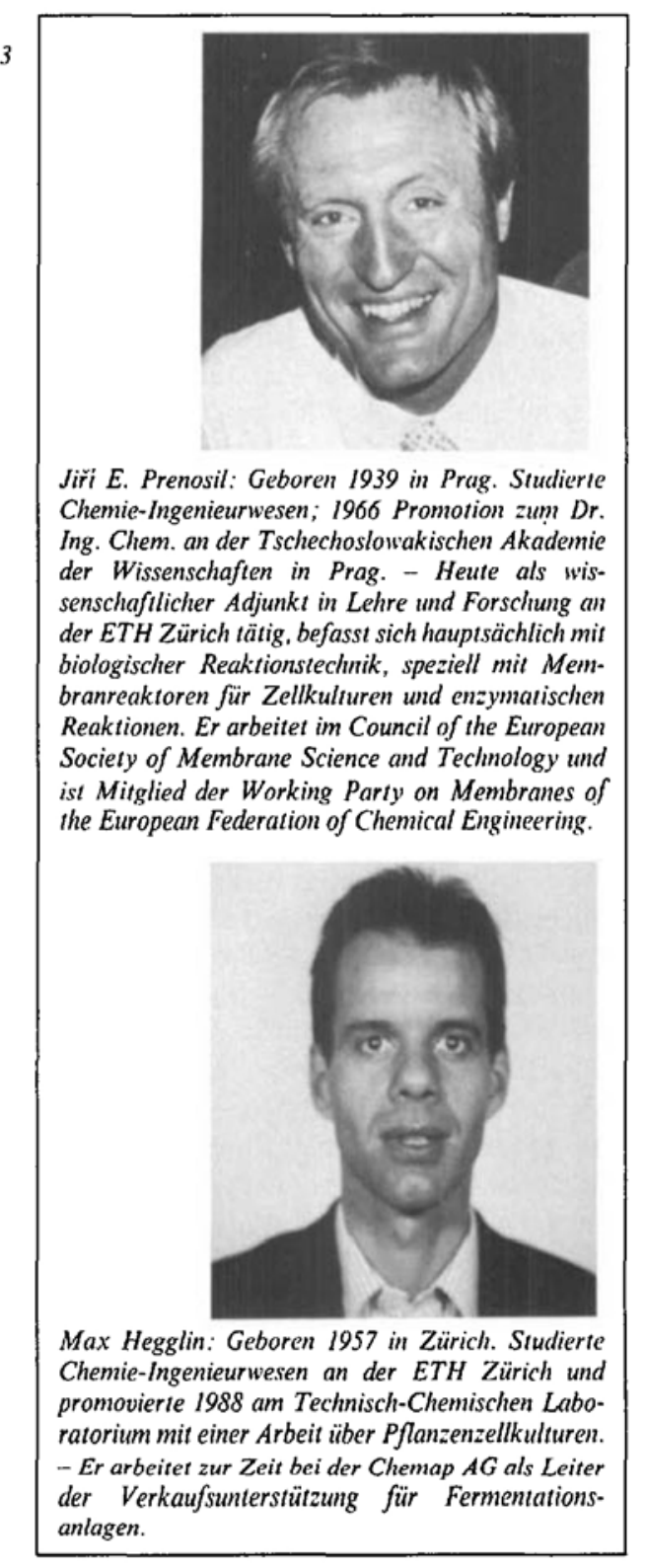

Vergleich zu Mikroorganismen viel langsamer, was die Anwendung von hochsterilen Apparaten und entsprechend aufwendiger Verfahren erfordert. Mehrstufige Reaktoren, wobei die ersten Reaktorstufen hauptsächlich zur Anzüchtung von genügend Biomasse bestimmt sind, können das Problem des langsamen Wachstums vermindern.

\subsection{Niedrige Produktionsrate}

Die interessierenden Inhaltsstoffe sind meist sekundäre Metaboliten, Stoffwechselprodukte, die die Pflanze für das Wachstum und die Vermehrung nicht unbedingt benötigt, die ihr aber in der Konkurrenz mit anderen Pflanzen, gegen Schädlinge oder widrige Umwelteinflüsse Vorteile bringen. Da sie aus primären Metaboliten synthetisiert werden, ist ihre Produktion meistens nicht unabhängig vom Wachstum, kann aber oft beeinflusst werden. So erhöhten Knobloch und Berlin ${ }^{[2]}$ die Produktion durch Limitierung von Phosphat im Medium. Frischknecht und Baumann ${ }^{[3]}$ erhöhten die Alkaloidproduktion schwach produzierender Zellen von C.arabica durch Stimulation mit Licht um den Faktor 150 . 
Durch die Zugabe von Chemikalien ${ }^{14}$ oder Mikroorganismenbestandteilen (Elicitoren) ${ }^{[s]}$ konnte die Produktion von Abwehrstoffen gegen Mikroorganismen (Phytoalexine) induziert werden.

Dougall ${ }^{[6]}$ erstellte 1985 eine Liste von Produkten aus Zellkulturen mit einer Ausbeute, bezogen auf das Trockengewicht, von mehr als $1 \%$. Für drei Inhaltsstoffe war die Ausbeute grösser als $20 \%$.

Zwei Arten von Pflanzenzellprodukten werden unterschieden: eine erste Gruppe, die in das umgebende Medium ausgeschieden wird, und eine zweite, die in der Zelle, meist den Vacuolen, verbleibt. Dieser Unterschied beeinflusst die Prozessführung entscheidend: Es wurde versucht, die Ausscheidung eines Stoffes generell zu ermöglichen oder die Produktverteilung zu verbessern. Durch Zugabe von Absorbentien zum Medium hielten Becker et al. ${ }^{[7]}$ die Konzentration des gewünschten Stoffs tief und erreichten so eine Erhöhung des totalen extrazellulären Anteils.

Zell- und Vacuolenmembran können für die gewünschten Inhaltsstoffe permeabilisiert werden. Parr et al. ${ }^{[8]}$ beschrieben dafür in Frage kommende Methoden und die damit verbundenen Probleme der Zellschädigung. Unter anderem gelang eine Permeabilisierung durch Behandlung der Zellen mit Dimethylsulfoxid ${ }^{[9]}$ oder durch Erhöhung der Ionenstärke des $\mathrm{Me}$ diums $^{[10]}$

\subsection{Scherempfindlichkeit}

Das Wachsen von Zellen in Aggregaten und Konglomeraten führt oft zu Mischproblemen in Bioreaktoren. Da die grossen Gebilde rasch sedimentieren, können Schichten entstehen, die nicht mehr genügend mit Nährstoffen versorgt werden. Um dies zu verhindern, wird üblicherweise die Suspension durch einen Rührer oder durch Einblasen von Luft in Bewegung gehalten. Durch das Mischen wird jedoch Energie in das System eingebracht, was eine Schädigung der Zellen zur Folge haben kann.

Schon 1977 machten Wagner und Vogelmann ${ }^{(11)}$ auf die hohe Scherempfindlichkeit von Pflanzenzellen bei der Kultivation in Bioreaktoren unterschiedlichen Typs aufmerksam. Neuere Berichte deuten auf eine geringere Scherempfindlichkeit hin, wobei jedoch eine Anpassung der Zellen an die Scherbeanspruchung vermutet wird ${ }^{[12]}$

Cherry und Papoutsakis ${ }^{[13]}$ führen den Scherstress auf Turbulenz und Kollisionen zurück. Zellen können durch Stösse von Zellaggregaten gegeneinander oder gegen feste oder bewegliche Reaktorteile sowie durch Wechselwirkung zwischen Zellen und turbulenter Strömung geschädigt werden. Tramper et al. ${ }^{[14]}$ fanden eine Schädigung von scherempfindlichen Insektenzellen durch die Bildung, das Aufsteigen und das Platzen an der Oberfläche von Gasblasen. Es sollte daher nur soviel Energie in das System eingebracht werden wie notwendig ist, um die Konzentration des limi- tierenden Nährstoffs, üblicherweise Sauerstoff, im ganzen Bioreaktor auf einem genügenden Niveau zu halten. Insbesondere sind hohe Turbulenz und Relativgeschwindigkeiten der Zellen zu Reaktorteilen, eventuell auch eine direkte Begasung, zu vermeiden.

\section{Reaktoren für Pflanzenzellkulturen}

Die Techniken zur Kultivation von Pflanzenzellen wurden grösstenteils von mikrobiellen Fermentationen übernommen und an die speziellen Bedürfnisse der Pflanzenzellen angepasst. In Tabelle 1 sind einige Besonderheiten von Pflanzenzellen im Vergleich zu Mikroorganismen aufgeführt. Diese Unterschiede beeinflussen Wahl und Auslegung des Reaktors.

Für Suspensionen wurden vor allem zwei Typen von Reaktoren angewendet, Rührreaktoren und Air-Lift-Reaktoren. Gerührte Reaktoren mit über $1 \mathrm{~m}^{3}$ Volumen wurden erfolgreich zur Kultivation von pflanzlichen Zellen benutzt, doch setzten sich wegen ihres einfachen Aufbaus und der geringeren Scherung im Pilotmaßstab mehrheitlich die Air-Lift-Reaktoren durch, in denen gute Resultate sowohl bezüglich des Wachstums als auch der Produktion erreicht wurden ${ }^{15,16]}$.

Es zeigte sich jedoch auch, dass in AirLift-Reaktoren bei Zelldichten von über 20 $\mathrm{g} / \mathrm{L}$ wegen der hohen Viskosität der Suspension Probleme beim Mischen (Totzonen) und beim Gastransfer auftreten ${ }^{[17]}$.

In Rührreaktoren wurden anstelle der bei Fermentationen üblichen Turbinen langsam drehende Rührer mit grossen Rührblättern eingesetzt. So verwendete Tanaka $^{[18]}$ in einem 5 L-Reaktor einen langsam drehenden (60 UpM) modizifierten Ankerrührer und erreichte mit ca. 30 $\mathrm{g} / \mathrm{L}$ die höchste Zelldichte für Reaktoren im Pilotmaßstab. Für die Produktion von Rosmarinsäure durch Zellkulturen wurde ein Wendelrührer verwendet ${ }^{[19]}$.

Die Immobilisierung von Zellen hat mehrere Vorteile. Es ist möglich, höhere Zelldichten zu erreichen und damit, bei gleicher Produktivität, höhere Konzentrationen des ins Medium abgegebenen Produkts zu erhalten, wobei allein durch die Immobilisation die Produktivität erhöht werden konnte ${ }^{[20]}$. Durch die Immobilisation werden scherempfindliche Zellen geschützt; die vereinfachte Trennung von Zellen und Medium erleichtert Mediumswechsel und Produktgewinnung ${ }^{[21]}$
Werden die Zellen in einer Matrix fixiert (z.B. Alginat, Polyurethanschaum), so muss ihr Wachstum kontrolliert werden, da sie sonst aus der Matrix herauswachsen und in Suspension gehen ${ }^{[22]}$. Ein Membranreaktor, der das Zellwachstum zulässt, wurde von Taya et al. ${ }^{[23]}$ entwickelt. Dieses System gestattet die kontinuierliche Ernte von Zellen, eignet sich also auch fü Produkte, die nicht in das Medium abgegeben werden. Cho und Shuler ${ }^{[24]}$ entwickelten einen Mehrmembranreaktor, in welchem die Zellen zwischen einer hydrophilen und einer hydrophoben Membran eingeschlossen sind und durch diese mit gelösten Nährstoffen bzw. Sauerstoff versorgt werden. Eine weitere hydrophobe Membran im Reaktor ermöglicht die Extraktion von Produkten aus dem Nährmedium in ein organisches Lösungsmittel.

Spezielle Reaktoren für Pflanzenzellen sind der Drehtrommelreaktor ${ }^{[25]}$ und der Taylor-Wirbel-Reaktor ${ }^{[26]}$, bei dem die Zellen zwischen zwei konzentrischen Zylindern, von denen sich einer dreht, kultiviert werden.

\section{Zellen und Medium}

Für eigene Untersuchungen wählten wir die im folgenden angegebenen Bedingungen.

\section{Zellkulturen}

Von den verwendeten Coffea arabica (von T.W. Baumann und P.W. Frischknecht, Institut für Pflanzenbiologie, Universität Zürich) und Nicotina tabacum (von $P$. Brodelius, Institut für Biotechnologie, ETH Zürich) wurden nur die Kaffeezellen permanent selber gehalten. Wo nicht anders spezifiziert, wurden alle Versuche mit Coffea arabica durchgeführt.

\section{Suspensionskulturen}

$100 \mathrm{~mL}$ Zellsuspension wurden in $250 \mathrm{~mL}$-Erlenmeyerkolben, mit doppelter Aluminiumfolie verschlossen, auf einem Rundschüttler mit $120 \mathrm{UpM}$ im Dunkeln bei Raumtemperatur gehalten und wöchentlich subkultiviert.

\section{Calluskulturen}

Callus wurde auf mit Agar verfestigtem Medium im Dunkeln bei $25^{\circ} \mathrm{C}$ gehalten und monatlich subkultiviert.

\section{Nährmedium}

Als Basalmedium diente das von Mura-

Tabelle 1. Besonderheiten von Pflanzenzellkulturen im Vergleich mit Mikroorganismen (TG = Trockengewicht).

\begin{tabular}{ll}
\hline Eigenschaft & Unterschied zu Mikroorganismen \\
\hline Grösse & $>10 \mu \mathrm{m}$ \\
Aggregatbildung & Aggregate verschiedenster Grösse bis ca. $10 \mathrm{~mm}$ \\
Wachstum & langsam, Verdoppelung in Tagen \\
Respiration & ca. $10 \mathrm{mal}$ geringer als bei Bakterien, \\
maximal $5 \mathrm{mmol} \mathrm{O}_{2} / \mathrm{h} \cdot \mathrm{g}(\mathrm{TG})$ & $\begin{array}{l}\text { hach } \\
\text { verschieden differenzierte Arten mit unterschiedlicher Morphologie } \\
\text { Differenzierung }\end{array}$ \\
\hline
\end{tabular}


shige und Skoog (1962) entwickelte Medium (Flow Laboratories, Irvine, Schottland), dem Cystein, Thiamin $\cdot \mathrm{HCl}$, Kinetin und 2,4-D (Tabelle 2) ${ }^{[27]}$ zugegeben wurde.

\section{Analysemethoden}

Aus praktischen Gründen wurden mehrere Methoden zur Bestimmung der Zellmasse angewendet:

- Nassgewicht der Zellen nach Waschen und Abtropfen;

- Frischgewicht der Zellen nach Waschen und Abnutschen ( 2 min);

- Trockengewicht der Zellen nach Waschen, Abnutschen und Trocknen im Ofen bei $80^{\circ} \mathrm{C}$ bis zur Gewichtskonstanz;

- die spezifische Leitfähigkeit des Mediums wurde für indirekte Zellmassebestimmung gemessen (Philipps PW 9527).

\section{Fliessbett-Reaktorsystem}

\subsection{Grundlagen}

Ein idealer Pflanzenzellreaktor muss mit extrem hohen Zelldichten bei sehr niedriger Scherbeanspruchung arbeiten. Diese Forderungen kann ein Fliessbettreaktor erfüllen.

Suspendierte Pflanzenzellen haben die Eigenschaft, in Aggregaten zu wachsen, deren Grösse von den Scherbedingungen abhängt. Das Wachsen in Aggregaten kann als natüriche Immobilisation betrachtet werden, die durch die Kultivation unter scherarmen Bedingungen und die Auswahl von Zellinien mit hoher Aggregatbildungstendenz gefördert werden kann. Da die gegenüber einzelnen Zellen grösseren Aggregate höhere Sinkgeschwindigkeiten aufweisen, eignen sie sich zum Einsatz in einem Fliessbettreaktor. Dabei lässt sich eine sehr hohe Zelldichte unter scherarmen Bedingungen erreichen; erforderlich ist aber intensiver Stofftransport, da diese Zellmasse mit genügend Sauerstoff versorgt werden muss.

Geringere Scherkraft und grosser Massentransfer lassen sich jedoch am selben Ort nicht erreichen. Erhöht man z. B. die Turbulenz in einem System, um mehr Transfer und bessere Vermischung zu bewirken, so nimmt auch die Scherbeanspruchung der Zellen zu.

Wird die Begasung getrennt von den restlichen Reaktorfunktionen in zellfreiem Medium durchgeführt, so lassen sich die Bedingungen optimieren, ohne dass auf die Scherempfindlichkeit der Zellen Rücksicht genommen werden muss. Eine zellfreie Belüftung bedingt, dass das Medium abgetrennt und zur Belüftungseinheit geleitet wird. Die einfachste Methode zur Trennung ist die Ausnutzung der Schwerkraft. Bei einem Fliessbettreaktor ist eine solche Trennung systemimmanent: Das am oberen Ende austretende sauerstoffarme
Tabelle 2. Konzentrationen der Zusätze im Medium und in den Zusatzlösungen sowie pH-Werte der Medien.

\begin{tabular}{llll}
\hline & $\begin{array}{l}\text { Medium } \\
\text { C.arabica } \\
\mathrm{mg} \cdot \mathrm{L}^{-1}\end{array}$ & $\begin{array}{l}\text { N.tabacum } \\
\mathrm{mg} \cdot \mathrm{L}^{-1}\end{array}$ & Zusatzlösungen \\
\hline Cystein & 10.0 & - & $\mathrm{mg} \cdot \mathrm{mL}^{-1}$ \\
Thiamin $\cdot \mathrm{HCl}$ & 0.9 & - & 1.0 \\
Kinetin & 0.2 & 0.2 & 1.0 \\
$\left.2,4-\mathrm{D}^{\mathrm{a}}\right)$ & 1.0 & - & 0.2 \\
IAA $^{\text {b) }}$ & - & 2.0 & 0.2 \\
\hline $\mathrm{pH}$ & 5.7 & 6.0 & 0.2 \\
\hline
\end{tabular}

a) 2,4-Dichlorphenoxyessigsäure; ${ }^{b}$ ) Indolessigsäure.

eigentliche Kolonne und die Beruhigungszone). Als Belüftungseinheit ist ein Kessel mit einem Arbeitsvolumen von $1 \mathrm{~L}$ angeschlossen, der mit einem Magnetstab gerührt wird. Das Medium wird im Kreislauf über die Begasungseinrichtung von unten in die Kolonne gepumpt, so dass die Schicht von Zellen und Aggregaten expandiert oder fluidisiert wird. Das Volumen in den Leitungen beträgt ca. $150 \mathrm{~mL}$. Zwei zusätzliche Medium-Kreisläufe können geschaltet werden: Ein Kurzschluss vor dem Zellreaktor erlaubt die Zirkulation von Medium ohne Sauerstoffsenke und somit die Eichung der Sauerstoffelektrode; ein Kurzschluss vor der Belüftungseinheit führt zu einem Kreislauf ohne Sauerstoffquelle, was die Messung des Sauerstoffverbrauchs (instationär) der Zellen ermöglicht.

Im Kreislauf (Fig. 1) gibt es neben der Sauerstoffelektrode eine Leitfähigkeitsmesszelle, einen Temperaturfühler und ein Rotameter, das ebenfalls kurzgeschlossen werden kann. Die Verbindungen der einzelnen Apparaturen wurden durch Siliconschläuche $(7 \times 9 \mathrm{~mm})$ hergestellt, die bei

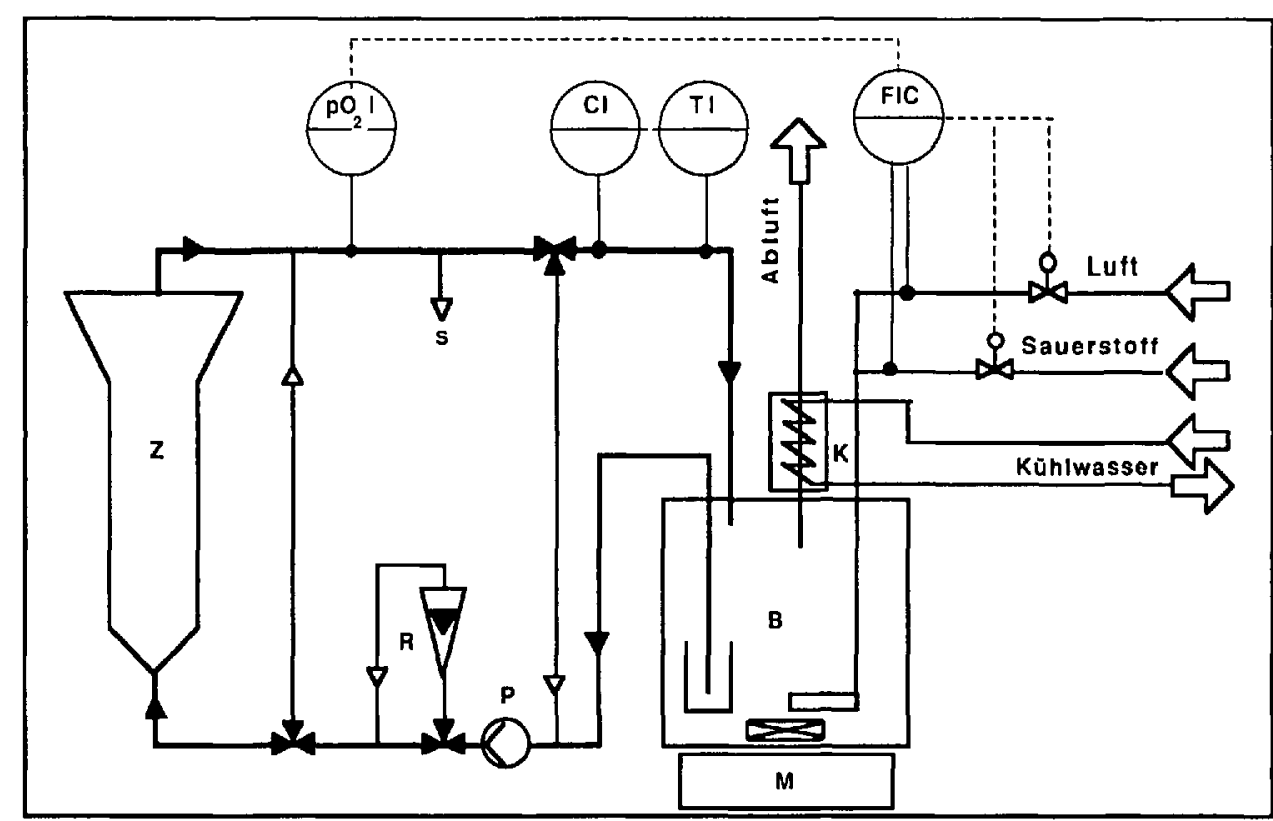

Fig. 1. Fliessbett-Reaktorsystem. Z: Zellreaktor; B: Begasungsgefäss; P: Zirkulationspumpe; R: Rotameter; $K$ : Rückflusskühler; $M$ : Magnetrührer; $S$ : Probenahme; $p \mathrm{O}_{2} I, C I$, TI: Messung von Sauerstoffpartialdruck, spezifischer Leitfähigkeit und Temperatur; FIC: Messung und Kontrolle (über gelösten Sauerstoff) der Luft- und Sauerstoffzufuhr. 
den Versuchen zur Bestimmung der Sauerstoffaufnahmeraten in einen PVCSchlauch $\left(3 / 8^{\prime \prime} \times 4 / 8^{\prime \prime}\right)$ gezogen waren. Der Sauerstoffpartialdruck im Medium am Ausgang des Zellreaktors konnte über die Luft- oder Sauerstoffzufuhr zum Belüftungsgefäss geregelt werden.

\section{Experimente und Resultate}

\subsection{Zellkultur mit grossen Aggregaten}

Um ein Ausschwemmen von Zellen aus dem Fliessbettreaktor möglichst zu vermeiden, wurde als Inoculum eine Kultur mit einem hohen Anteil von Aggregaten mit Durchmessern bis ca. $5 \mathrm{~mm}$ (kleine Aggregate wurden ausgewaschen) gewählt. Während des ganzen Versuches wurde das Begasungsgefäss mit $0.01 \mathrm{vvm}$ belüftet, womit die Konzentration des gelösten Sauerstoffs am Ausgang des Reaktors zwischen 40 und $60 \%$ Sättigung gehalten werden konnte.

Fig. 2 zeigt das Zellwachstum, ausgedrückt durch das Volumen der sedimentierten Zellschicht und die Glucosekonzentration im Medium. Im Vergleich zu einer parallelen Schüttelkuitur mit gleichen Anfangskonzentrationen ist die Glucoseaufnahme im Fliessbett etwas langsamer, doch ist der Verlauf in beiden Kulturen gleich.

Fig. 3 zeigt die Leerrohrgeschwindigkeit (LRG) und die Expansion der Zellschicht in diesem Versuch. Trotz der Wahl einer Kultur mit hohem Anteil grosser Aggregate wurden so viele Teilchen aus dem Fliessbett ausgeschwemmt, dass das $\mathrm{Me}$ dium im Belüftungsgefäss leicht getrübt wurde. Der Zirkulationsfluss wurde nach einem Tag reduziert, worauf sich innert weniger Stunden praktisch keine Zellen mehr im Kreislauf befanden. Eine schwache Erhöhung der LRG (bei $t=3 \mathrm{~d}$ ) verursachte neben einer Expansion der Zellschicht das Ausschwemmen von kleinen Aggregaten, doch war nun das umlaufende Medium nach ca. 2 Stunden wieder zellfrei, ohne dass der Fluss reduziert werden musste. Die ausgeschwemmten Aggregate gelangten über den Begasungskreislauf wieder zurück in das Fliessbett, wo sie zum Teil an anderen Aggregaten haften blieben.

Eine weitere starke Erhöhung der LRG (bei $t=5 \mathrm{~d}$ ) führte zu einer grösseren $\mathrm{Ex}$ pansion der Zellschicht, doch wurden kaum noch Aggregate ausgeschwemmt. Mit zunehmendem Aggregatwachstum verringerte sich der Anteil kleinster Teilchen $(d<1 \mathrm{~mm})$, womit die Expansion abnahm, bis die Zellschicht praktisch zu einem Festbett wurde. Fig. 4 und Fig. 5 zeigen den obersten und den unteren Teil der Zellschicht.

Um die Zellschicht während der ganzen Versuchsdauer zu expandieren, muss die LRG der zunehmenden Grösse der Aggregate angepasst werden. Der Trockenge-

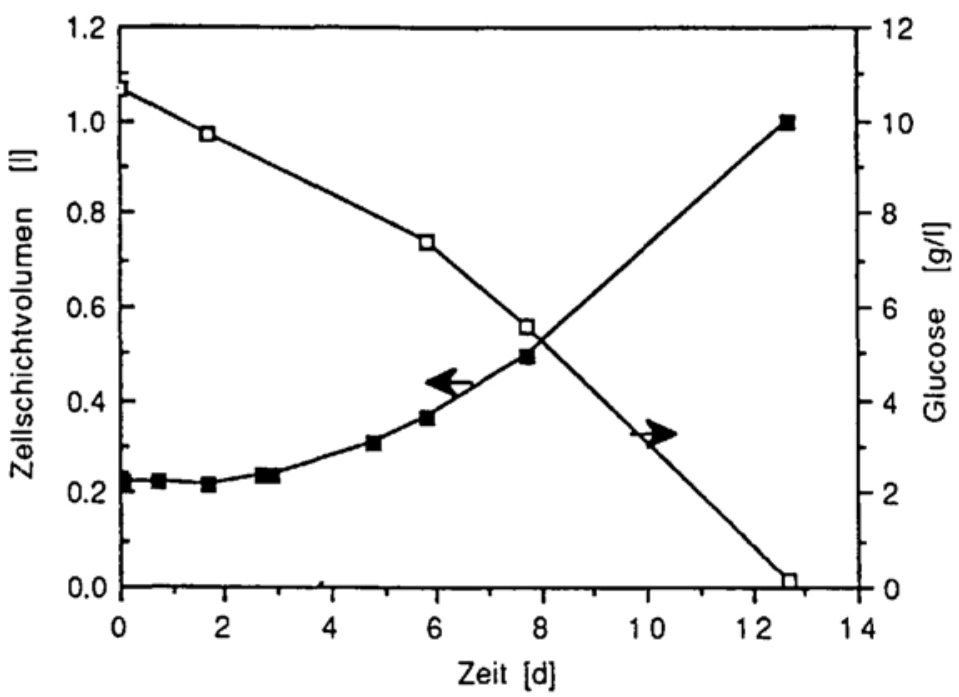

Fig. 2. Coffea arabica in Fliessbettreaktor.

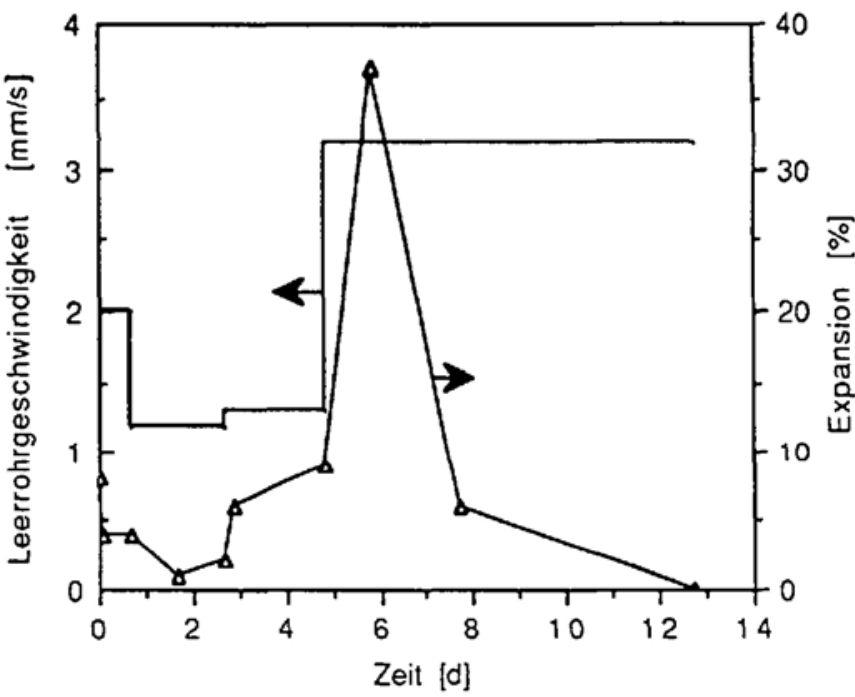

Fig. 3. Lehrrohrgeschwindigkeit und Expansion der Zellschicht in Kultur mit grossen Aggregaten.

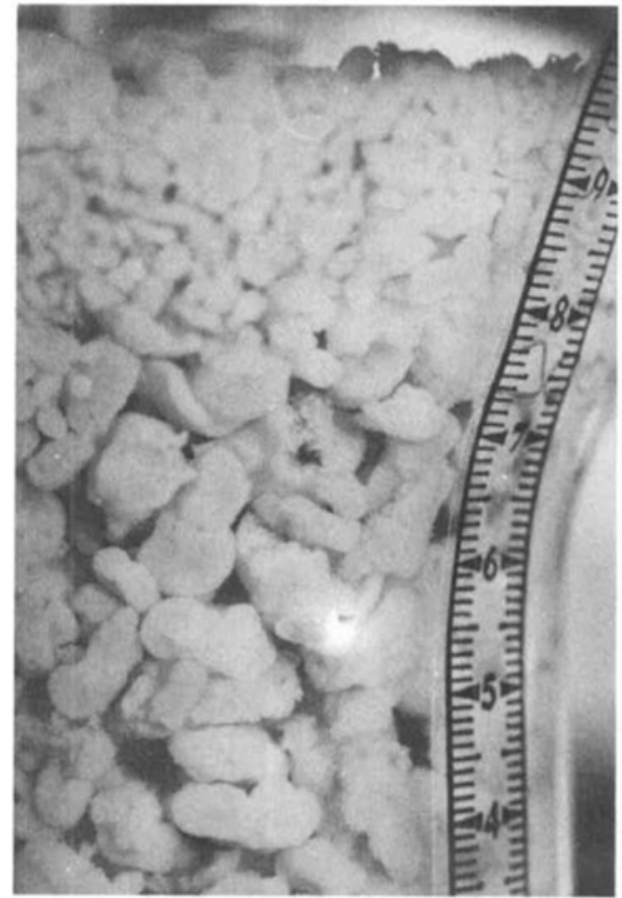

Fig. 4. Oberste Schicht im Fliessbettreaktor. Skala in $\mathrm{cm}$

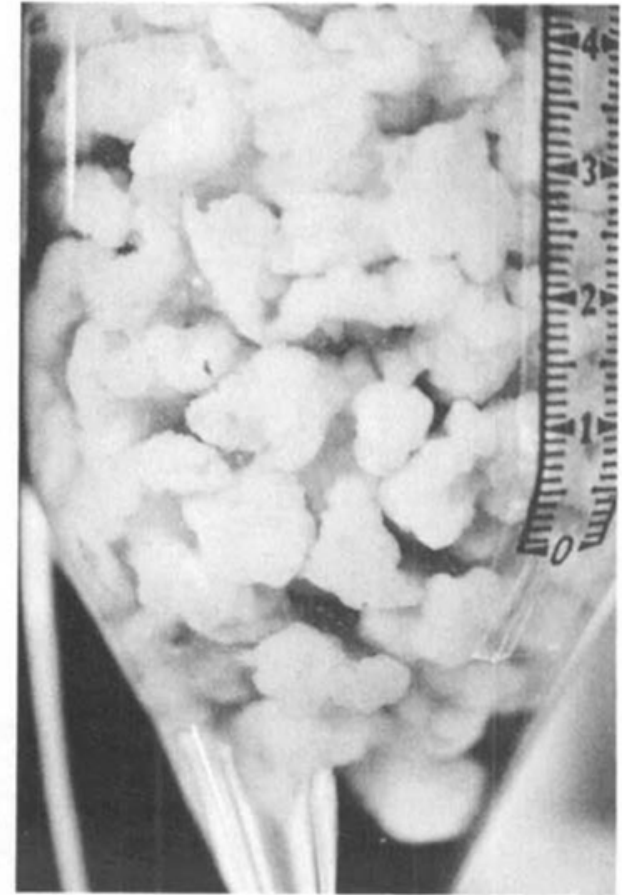

Fig.5. Unterer Teil des Fliessbettreaktors. Skala in $\mathrm{cm}$. 


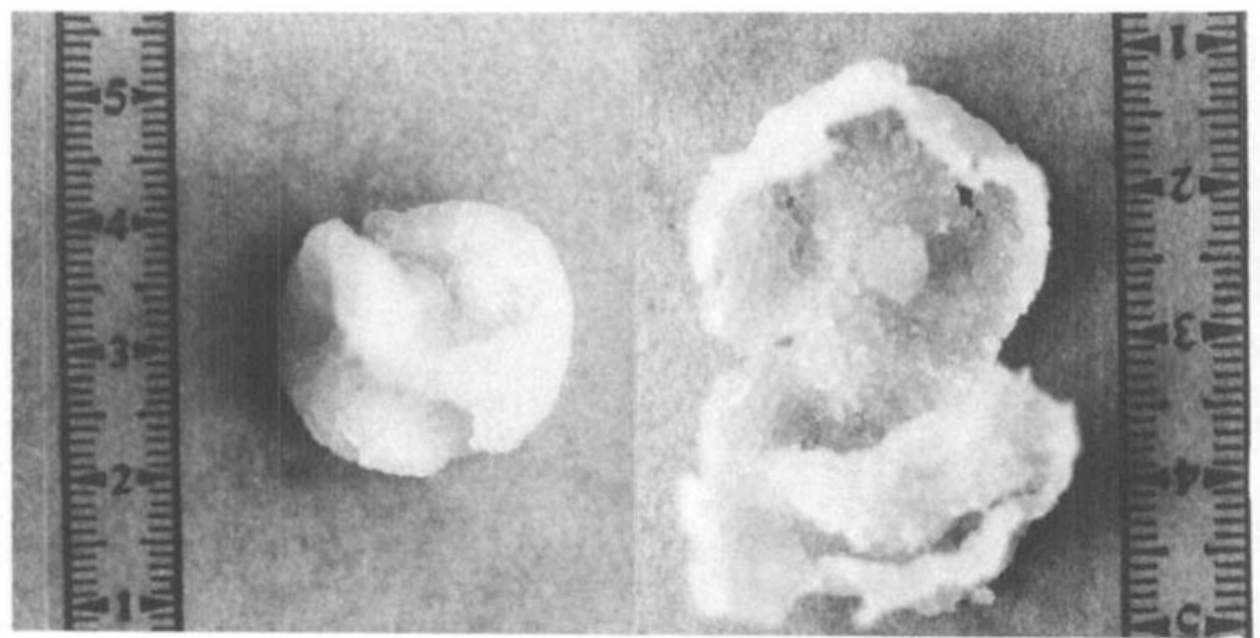

Fig. 6. Hohlaggregat aus dem Fliessbettreaktor. Skala in cm.

wichtsanteil der am Ende des Experiments geernteten Zellen betrug nur noch $50 \%$ der ursprünglich eingesetzten, auch hatte sich deren Aussehen verändert. Anstelle der eher rundlichen Aggregate des Inoculums entstanden Flocken, die sich mit zunehmender Grösse zu Hohlkugeln schlossen. Fig. 6 zeigt ein solches Aggregat aus dem Fliessbett sowie nach dem Öffnen.

\subsection{Zellkultur mit kleinen Aggregaten}

Die Verwendung von kleinen Aggregaten hatte eine längere "Lag»-Phase zur Folge, die anschliessenden Wachstumsphasen verliefen parallel (Fig. 7).

Auch bei diesem Versuch bildeten sich flockenartige Aggregate und Hohlkugeln, wobei jedoch nur einzelne Aggregate am Eingang des Fliessbetts eher rundlich und nicht hohl waren. Die Expansion der Zellschicht ist zunächst trotz der kleineren LRG im Vergleich zum vorhergehenden Versuch deutlich grösser und variiert im
Bereich $30-70 \%$. Innerhalb eines Tages fiel sie jedoch bei gleichbleibender LRG völlig zusammen. Ein Grossteil der bis anhin fluidisierten Aggregate musste praktisch gleichzeitig eine Grösse und Dichte erreicht haben, die mit der bestehenden LRG nicht mehr zu fluidisieren war. Da in beiden Versuchen der Zeitpunkt des Einbruchs der Expansion mit dem Ende der "Lag»-Phase übereinstimmte, könnte auch eine damit zusammenhängende Änderung der Oberflächeneigenschaften der Zellaggregate diesen Effekt verursacht haben.

Fig. 8 zeigt den Fliessbettreaktor mit Zellen von $C$. arabica. Deutlich ist die Schichtung nach Grösse (Sinkgeschwindigkeit) erkennbar. Die Trennung von Zellschicht und Medium ist scharf. Nur einzelne Teilchen steigen in die Beruhigungszone auf, von wo sie wieder absinken oder über den Belüftungskreislauf zurück in das Fliessbett gelangen. Fig. 9 zeigt vergrössert den oberen Rand der Zellschicht.

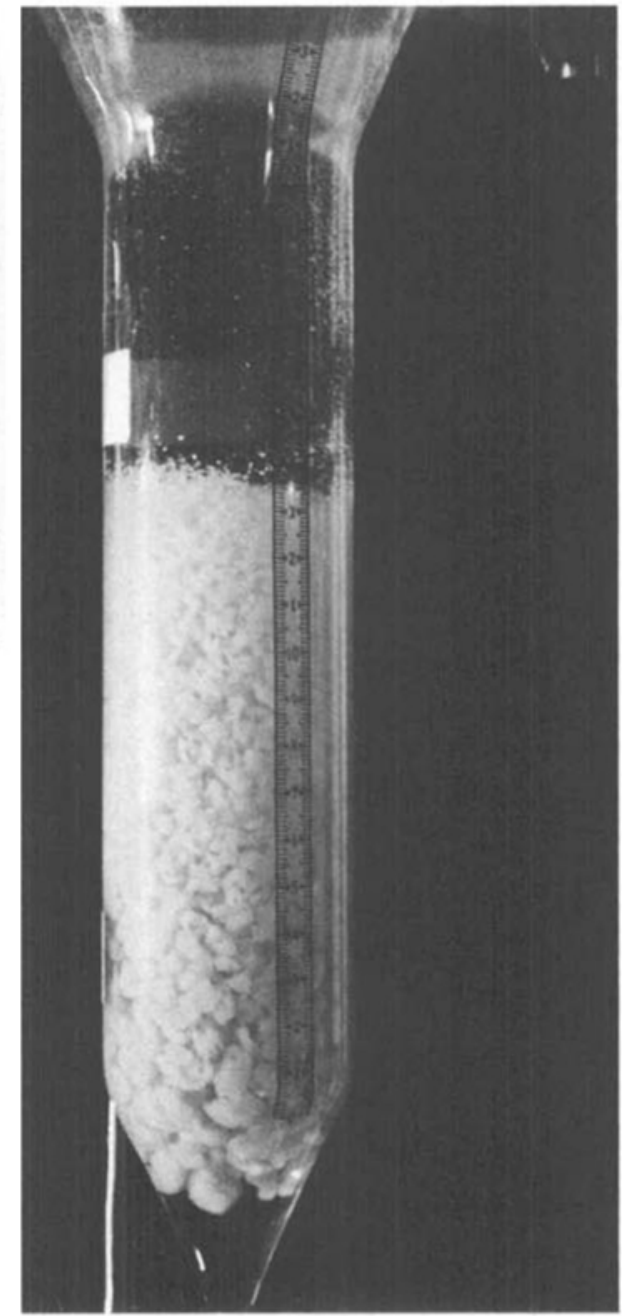

Fig. 8. Fliessbettreaktor mit Zellen von C.arabica.

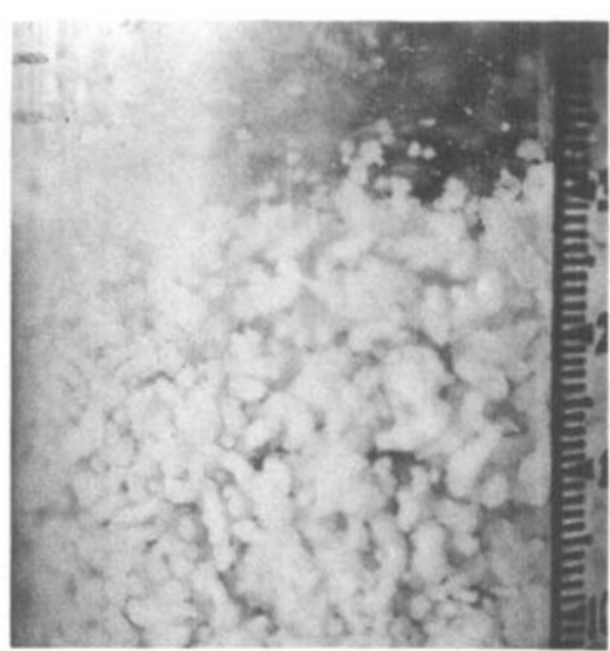

Fig. 9. Oberer Rand der fluidisierten Zellschicht.

\subsection{Beeinflussung der Länge der} "Lag"-Phase

Durch das Auswaschen von kleinen Zellaggregaten aus dem Inoculum mit frischem Medium wird auch konditioniertes Medium entfernt. Zusammen mit der kleinen Zelldichte zu Beginn eines Versuchs führt dies zu einer «Lag»-Phase, die gleich 
lang oder länger sein kann als die eigentliche Wachstumsphase. Die Folge ist eine ineffektive Ausnützung des Reaktors. Werden als Inoculum Zellen aus einem Fliessbettreaktor verwendet, so erübrigt sich ein Auswaschen von kleinen Aggregaten. Die Verwendung eines Teils des konditionierten Mediums aus einem vorangegangenen Versuch verkürzt die «Lag»Phase weiter. Fig. 10 zeigt Bedingungen und Resultate von drei aufeinanderfolgenden Batch-Kultivationen von $C$. arabica. Während beim ersten Ansatz die Zellen mit frischem Medium gewaschen wurden, was zu einer «Lag»-Phase von ca. 7 Tagen führte, wurden in den beiden nächsten Versuchen jeweils Zellen und Medium aus dem vorangegangenen Versuch eingesetzt und nur ungefähr ein Drittel des Mediums ersetzt. Bei diesen Ansätzen konnte dann praktisch keine «Lag»-Phase mehr beobachtet werden.

\subsection{Unterscheidung von Gebieten mit verschiedener Aggregatsgrösse}

Bei einem Versuch im Fliessbettreaktor entstand eine scharfe Trennung der Zellschicht (ZS) in Gebiete mit kleinen und grossen Aggregaten durch den Übergang von Hohlkugeln mit Durchmessern von ca. $10 \mathrm{~mm}$ zu kleineren, flockigen Aggregaten. Die Zellmassen dieser Schichten wurden getrennt bestimmt, die Ergebnisse sind in Tabelle 3 dargestellt. Der Trockengewichtsanteil der Zellen ist in beiden Gebieten etwa gleich, betrug jedoch nur ca. $60 \%$ des Inoculums. Die im Fliessbettreaktor wachsenden Zellen müssen andersartig sein als die des Inoculums aus einer Schüttelkultur, insbesondere ist die Dichte der Zellen im FBR kleiner. Die beiden Bereiche unterscheiden sich stark bezüglich Trockengewicht (TG) und Nassgewicht (NG), was auf unterschiedliche Porosität hinweist.

Tabelle 4 zeigt die mit der Monod-Gleichung (exponentielles Wachstum) berechneten Wachstumsraten des Trockengewichts und des Zellbettvolumens über die ganze Kultivationsdauer. Für das Volu-

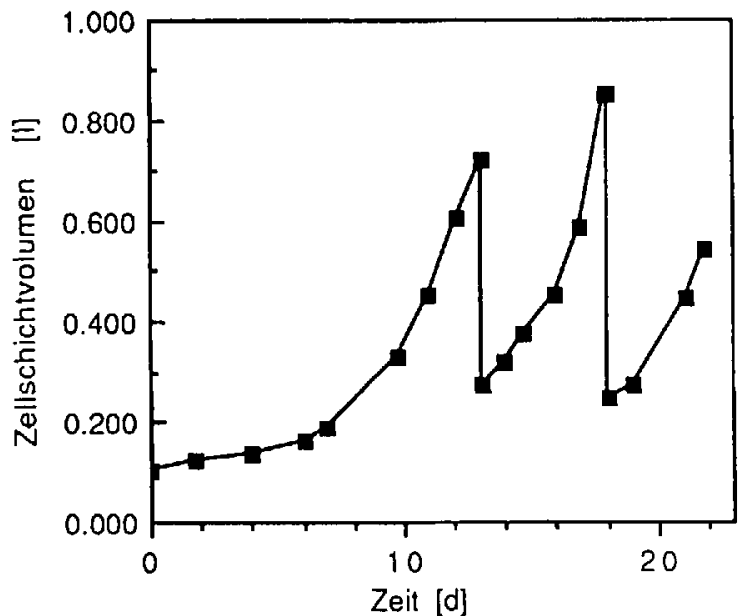

Fig. 10. Verlauf der Zellschichtvolumina in drei aufeinanderfolgenden Batch-Kulturen.

men ist zudem die analog bestimmte Rate für die Zeit von $t=10-12 \mathrm{~d}$, dem Bereich mit stärkster Volumenzunahme, angegeben. Das Wachstum des Volumens ist grösser als das der Zellmasse (NG und TG), die Porosität der Zellschicht muss sich daher während der Kultivation erhöht haben.

\subsection{Tabakzellen im Fliessbettreaktor}

Nach den erfolgreichen Versuchen mit Coffea arabica wurde im Fliessbettreaktor auch Nicotina tabacum eingesetzt (Fig. 11). Trotz der langen «Lag»-Phase konnten wir demonstrieren, dass mit $N$. tabacum eine weitere aggregatbildende Zellkultur im Fliessbettreaktor kultivierbar ist.

\section{Leistung des Fliessbettreaktors}

Die maximale Zelldichte, die sich im System erreichen lässt, ist bestimmt durch das maximal ausnützbare Volumen und die Zelldichte in diesem Volumen bezogen auf das totale Volumen, wobei das nutzbare Volumen nicht durch die sedimen-

Tabelle 3. Vergleich der Zellschichten mit grossen und kleinen Aggregaten.

\begin{tabular}{lllllllll}
\hline & Medium & $\begin{array}{l}\text { NG/ } \\
\text { Medium } \\
(\mathrm{g} / \mathrm{L})\end{array}$ & NG & TG & TG/NG & ZS & TG/ZS & NG/ZS \\
& $(\mathrm{L})$ & $(\mathrm{g})$ & $(\%)$ & $(\mathrm{L})$ & $(\mathrm{g} / \mathrm{L})$ & $(\mathrm{g} / \mathrm{L})$ \\
\hline Inoculum & 1.918 & 26 & 50 & 2.6 & 5.2 & 0.177 & 14.7 & 282 \\
Ernte total & & & 355.3 & 10.75 & 3.0 & 1 & 10.8 & 355 \\
kleine Aggregate & & & 183.5 & 5.45 & 3.0 & 0.64 & 8.5 & 287 \\
grosse Aggregate & & & 171.8 & 5.3 & 3.1 & 0.36 & 14.7 & 477 \\
\hline
\end{tabular}

Tabelle 4. Wachstumsraten der Zellmasse und des Zellschichtvolumens.

\begin{tabular}{lll}
\hline$\mu \chi(\mathrm{TG})$ & $\left(t_{1}=0, t_{2}=13\right)$ & $0.11\left[\mathrm{~d}^{-1}\right]$ \\
$\mu \chi(\mathrm{NG})$ & $\left(t_{1}=0, t_{2}=13\right)$ & $0.15\left[\mathrm{~d}^{-1}\right]$ \\
$\mu_{\mathrm{V}}$ & $\left(t_{1}=0, t_{2}=13\right)$ & $0.16\left[\mathrm{~d}^{-1}\right]$ \\
$\mu_{\mathrm{V}}$ & $\left(t_{1}=10, t_{2}=12\right)$ & $0.30\left[\mathrm{~d}^{-1}\right]$ \\
\hline
\end{tabular}

tierte, sondern die expandierte Zellschicht eingenommen wird.

Die Dichten in der expandierten Zellschicht am Ende der Kultivationen variierten für Coffea arabica zwisschen 9.9 und $14.4 \mathrm{~g}$ (TG)/L, für Nicotina tabacum um $7.8 \mathrm{~g}$ (TG)/L. Bei einem nutzbaren Volumen von $1 \mathrm{~L}$ und einem totalen Volumen von $2.1 \mathrm{~L}$ werden diese Werte für das ganze System etwa halbiert; sie sind somit niedriger als der nicht optimierte Wert im Rührreaktor (11.8 g (TG)/L). Würde die Begasungsapparatur bezüglich des Sauerstofftransfers optimiert, könnte deren Volumen verkleinert werden, was zu einer höheren Zelldichte im System führt (die Volumina und Leistungen unserer Laborapparatur waren in keiner Weise optimiert).

Über die Coffeinproduktion können keine Angaben gemacht werden, da die Zellen die Alkaloidbildung stark reduzierten oder ganz einstellten.

\section{Schlussbemerkungen und Ausblick}

Die Testkultur Coffea arabica eignete sich gut für Versuche in unterschiedlichen Reaktortypen. Eine bessere Charakterisierung und Standardisierung der Zellen (Aggregatgrössenverteilung und Trockengewichtsanteil) würde Versuche mit identischen Anfangsbedingungen ermöglichen und die Reproduzierbarkeit erhöhen. Daten über die Scherempfindlichkeit wären erwünscht, um in gerührten Systemen die Bedingungen für Massentransfer und Biomasse zu optimieren.

Die Verwendung eines Fliessbett-Reaktorsystems empfiehlt sich für Kulturen mit geringen Anteilen von einzelnen Zellen und Konglomeraten weniger Zellen, sofern die Aggregatbildung erwünscht ist. Durch die externe Belüftung des zellfreien Mediums werden die Zellen nicht geschädigt, zudem kann bei der praktisch gleichbleibenden niedrigen Viskosität des Mediums belüftet werden. Das System eignet sich besonders für die batchweise Biomasseproduktion. Das Verhältnis von Inoculum- 


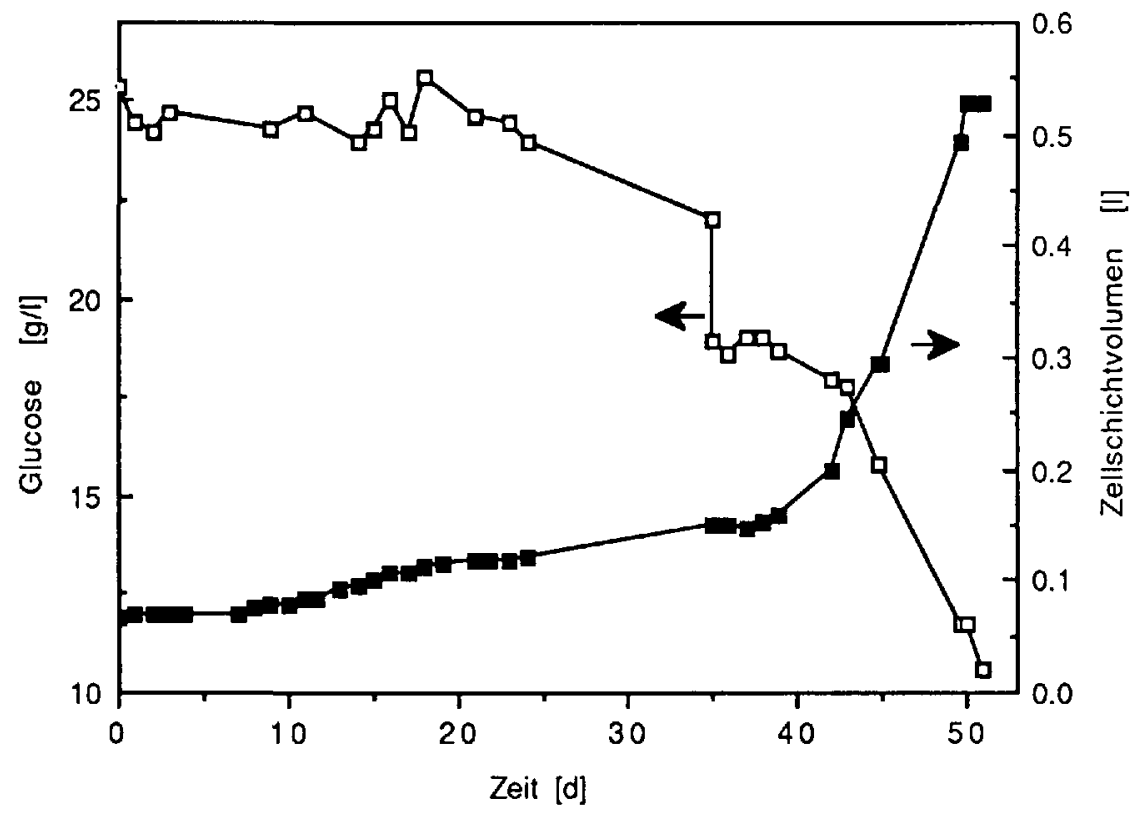

Fig. 11. Zellschichtvolumen und Glucoseaufnahme von Zellen von N. tabacum im Fliessbettreaktor. Partieller Mediumwechsel bei $t=35 d$.

grösse zu Mediumsvolumen könnte verbessert werden, wenn im Fliessbettreaktor auf die Beruhigungszone verzichtet würde. Ein in der Höhe verstellbares Ausflussrohr dieser Kolonne und Luft im Kolonnenkopf würde die Anpassung des Flüssigvolumens an das der Zellschicht erlauben. Kann auf die Beruhigungszone nicht verzichtet werden, so liesse sich mittels eines beweglichen Bodens des Fliessbetts derselbe Effekt erreichen.

Infolge der breiten, sich verändernden Grössenverteilung der Aggregate ist es jetzt noch schwierig, das Verhalten der Kultur genau zu beschreiben, was die Anwendbarkeit eines Reaktormodells erschwert. Für weitere Arbeiten drängen sich experimentelle Bestimmungen des Fluidisierungspunkts und Messungen von Verweilzeitverteilungen auf.

Unsere Arbeit wurde vom Schweizerischen Nationalfonds zur Förderung der wissenschaftlichen Forschung unterstützt (Projekt Nr. 2.892). Wir danken PD Dr. T.W. Baumann, Institut für Pflanzenbiologie der Universität Zürich, für seine Hilfe bei der Lösung pflanzenbiologischer Probleme sowie Frau V. Kaspar für Zellkultivierung und -unterhalt.

Eingegangen am 10.Juli 1989 [TR 38]
[1] G. F. Payne, M.L. Shuler, P. Brodelius, «LargeScale Plant-Cell Culture», in K. Lydersen (Ed) Large-Scale Cell Culture Technology. Hanser, München (1987), p. 193.

[2] K.H. Knobloch, J. Berlin, "Influence of Phosphate on the Formation of the Indole Alkaloids and Phenolic Compounds in Cell Suspension Cultures of Catharantus roseus, 1. Comparison of Enzyme Activities and Product Accumulation", Plant Cell Tissue Organ Culture 2 (1983) 333.

[3] P.M. Frischknecht, T. W. Baumann, «Stress-Induced Formation of Purine Alkaloids in PlantTissue Cultures of Coffea arabica», Phytochemistry 24(1985) 2255.

[4] N.T. Kenn, B. Bruegger, "Phytoalexins and Chemicals that Elicit their Production in Plants", $A C S$ Symp. Ser. 62 (1977) 447.

[5] C.A. West, "Fungal Elicitors of the Phytoalexin Response in Higher Plants', Naturwissenschaften 68 (1981) 447

[6] D. K. Dougall, «Chemicals from Plant-Cell Cultures: Yields and Variation", in M. Zaitlin, P. Day, A. Hollaender (Ed.): Biotechnology in Plant Science, Academic Press, Orlando FL (1985), p. 179

[7] H. Becker, J. Reichling, W. Bisson, S. Herold, "Two-Phase Culture; A New Method to Yield Lipophilic Secondary Products from Plant Suspension Cultures"), Proc. 3rd Eur. Congr. Biotechnol. $I$ (1984) 209.

[8] A.J. Parr, R.J. Robins, M.J.C. Rhodes, «Release of Secondary Metabolites by Plant-Cell Cultures», in C. Webb, F. Mavituna (Ed.): Plant and Animal Cells; Process Possibilities, Ellis Horwood, Chichester (1987), p. 229

[9] P. Brodelius, K. Nilsson, «Permeabilization of Immobilized Plant-Cells Resulting in Release of Intracellulary Stored Products with Preserved Cell Viability", Eur. J. Appl. Microbiol. Biotechnol. 17 (1983) 275 .
[10] H. Tanaka, C. Hirao, H. Semba, Y. Tozawa, S. Ohmomo, "Release of Intracellulary Stored 5'. Phosphodiesterase with Preserved Plant-Cell Viability", Biotechnol. Bioeng. 27 (1985) 890.

[11] F. Wagner, H. Vogelmann, "Cultivation of PlantTissue Cultures in Bioreactors and Formation of Secondary Metabolites", in W. Barz, E. Reinhard, M.H. Zenk (Ed.): Plant Tissue Culture and its Biotechnological Applications, Springer, Berlin (1977), p. 245.

[12] M. W. Fowler, P. Bond, A. H. Scragg, «Developments in Plant-Cell Culture Technologym, in $\mathrm{H}$. Chmiel (Ed.): Biochemical Engineering, Gustav Fischer, Stuttgart (1987).

[13] R.S. Cherry, E.T. Papoutsakis, «Hydrodynamic Effects on Cells in Agitated Tissue Culture Reactors", Bioprocess Eng.l (1986) 29.

[14] J. Tramper, D. Joustra, J. M. Vlak, «Bioreactor Design for Growth of Shear-Sensitive Insect Cells" in C. Webb, F. Mavituna (Ed.): Plant and Animal Cells; Process Possibilities, Ellis Horwood, Chichester (1987), p. 125.

[15] M.H. Zenk, H. El-Shagi, H. Arens, J. Stockigt, E. W. Weiler, B. Deus, «Formation of the Indole Alkaloids Serpentine and Ajmalicine in Cell-Suspension Cultures of Catharanthus roseus, in W. Barz, E. Reinhard, M.H. Zenk (Ed.): Plant Tissue Culture and its Biotechnological Applications. Springer, Berlin (1977), p. 27

[16] N. J. Smart, M.W. Fowler, «Mass Cultivation of Catharanthus roseus Cells Using a Nonmechanically Agitated Bioreactor', Appl. Biochem. Biotechnol. 9 (1984) 209

[17] Wilson, G. "Growth and Product Formation in Large-Scale and Continuous Culture Systems» in T. A. Thorpe (Ed.): Frontiers of Plant Tissue Cutcures, Bookstore, University of Calgary (1978) p. 169.

[18] H. Tanaka, «Technological Problems in Cultivation of Plant Cells at High Densitys, Biotechnol. Bioeng. 23 (1981) 1203.

[19] B. Ulbrich, W. Weisner, H. Arens, "Large-Scale Production of Rosmarinic Acid from Plant-Cell Cultures of Coleus blumei Benth", in K. H. Neumann, W. Barz, E. Reinhard (Ed.): Primary and Secondary Metabolism of Plant-Cell Cultures. Springer, Berlin (1985), p. 293.

[20] D. Haldimann, P. Brodelius, «Redirecting Cellular Metabolism by Immobilization of Cultured Plant Cells: A Model Study with Coffea arabica", Phyrochemistry 26 (1987) 1431.

[21] M. L. Shuler, O.P. Sahai, G. A. Hallsbby, «Entrapped Plant Cells», Ann. N.Y. Acad. Sci. 413 (1983) 373.

[22] P. Brodelius, K. Mosbach, «Immobilized Plant Cells», Appl. Biochem. Biotechnol. 7 (1982) 31

[23] M. Taya, M. Hegglin, K. H. Yoon, J. E. Prenosil, "A Novel Membrane Reactor for Plant-Tissue Cultures», Proc. Int. Congr. Membranes \& Membrane Processes (ICOM), Tokyo (1987), p. 629

[24] T. Cho, M. L. Shuler «Multimembrane Bioreactor for Extractive Fermentation", Biotechnol. Prog. 2 (1986) 53 .

[25] H. Tanaka, F. Nishijima, M. Suwa, T. Iwamoto, "Rotating Drum Fermenter for Plant-Cell Suspension Cultures», Bioteclmol. Bioeng. 25 (1983) pension 2359 .

[26] D. A. Janes, N.T. Thomas, J.A. Callow, «Demonstration of a Bubble-Free Annular-Vortex Membrane Bioreactor for Batch Culture of Red Beet Cells), Biotechnol. Tech. I (1983) 257.

[27] $M$. Hegglin, «Einsatz von aggregatbildenden pflanzlichen Zellkulturen in einem Fliessbettreaktor), Dissertation Nr. 8628, ETH Zürich (1988). 


\section{Eröffnung des Nachdiplomstudiums BIOTECHNOLOGIE am Technikum Winterthur Ingenieurschule}

Am 6. Dezember 1989 wurde das Nachdiplomstudium Biotechnologie am Technikum Winterthur Ingenieurschule (TWI) eröffnet. Hierbei geht es um die Verwirklichung eines Projekts (vgl dazu G. Wolf: Die Schweiz braucht den "Biotechnologen HTL", Chimia 42 (1988) 242), dem auch für die Bemühungen um Anerkennung der Schweizer Ingenieur-Diplome im Ausland - vor allem im Hinblick auf «EG 92»-Bedeutung zukommt.

Die European Federation of Biotechnology hat folgende Definition geprägt (29. Mai 1989): «Biotechnology is the integration of natural sciences and engineering sciences in order to achieve the application of organisms, cells, parts thereof and molecular analogues for products and services". Innerhalb der angewandten Biologie ist die Biotechnologie ein wichtiges Teilgebiet. Biotechnologie ist aber weit mehr als eine weitere Technologie, ihr Gedankengut könnte zur Überlebensstrategie von morgen werden. Fig. 1 zeigt, was die Einführung der Biotechnologie in der Abteilung für Chemie des TWI alles bewirkt hat. Mit der Eröffnung des Nachdiplomstudiums wird eigentlich der Einzug der Biologie in das Haus der Technik gefeiert. Die siamesischen Zwillinge Chemie und Biologie haben sich lange genug auseinanderentwickelt. Es ist ein Zeichen der Umkehr, dass der Nobel-Preis für Chemie 1989 an T. R. Cech und Sidney Altman für Arbeiten verliehen wurde, die zur Entdeckung von Ribonucleinsäuren (RNA) als neue Klasse von Biokatalysatoren geführt haben.

Nach dem Winterthurer Reform-Modell ist die Einführung der Biotechnologie der zweite Meilenstein auf dem Wege zum «Ingenieur 2000 », einer neuen Generation von Ingenieuren und Chemikern, die durch das Verständnis unserer Umwelt die gewaltigen Aufgaben der nachindustriellen Gesellschaft mit und nicht gegen die Natur lösen werden. Unsere Jugend ist gerne bereit, Biowissenschaften zu lernen. Seit Herbst 1989 sind im Chemielehrplan Biotechnologie, Mikrobiologie, Zellbiologie sowie Biochemie und Enzymologie eingegliedert. Fernziel ist, allen Ingenieuren mindestens eine Einführung in diese für ihre Tätigkeit im wahrsten Sinne vitalen Gebiete zu vermitteln. Unsere ersten Erfahrungen sind sehr ermutigend.

Nach einer über zehnjährigen Vorgeschichte wurde am 22. April 1988 in Zusammenarbeit mit 30 Spezialisten der Schweizer Biotechnologie aus Lehre, Forschung und Industrie ein Rahmenlehrplan für ein einjähriges Nachdiplomstudium Biotechnologie (NDSBT) erstellt, und nach der Vernehmlassung bei interessierten Kreisen konnte der definitive Lehrplan am 3. Februar 1989 beschlossen werden. Für die Entwicklung der Biotechnologie ist diese neue Ausbildungsmöglichkeit von grosser Bedeutung. Der Kanton Zürich hat dafür Fr. 3.4 Millionen bereitgestellt. Sponsoren aus Industrie- und Bankenkreisen unterstützten das Projekt mit Leistungen im Wert von insgesamt ca. Fr. 800000 . Sehr hilfreich ist auch, dass die ETH Zürich mit mehreren Instituten mitmacht (Institut für Biotechnologic, Mikrobiologisches Institut und Institut für Lebensmittelwissenschaft im Bereich CIM) Weiter sind beteiligt die Universität Zürich (Institut für Pflanzenbiologie, Molekularbiologie Hönggerberg) und die Universität Basel (Biozentrum). Sofern sich der fünfjährige Pilotversuch mit dem Nachdiplomstudium bewährt, ist ein Vollstudium "Biotechnologie» geplant.

Die wichtigsten Ziele des Nachdiplomstudiums sind

- Betreiben von Bioreaktoren (Fermentationsverfahren, Produktgewinnung);

- Auslegung von Bioreaktoren (Apparate- und Anlagenbau);

- Instrumentierung und Verfahrenssteuerung (Messund Regelungstechnik, Prozessleittechnik);

- Produktaufarbeitung (Down-stream Processing, Isolierungs- und Reinigungsverfahren, verfahrenstechnische Grundoperationen);

- Analytik (prozessbegleitende Analytik, Laboranaly

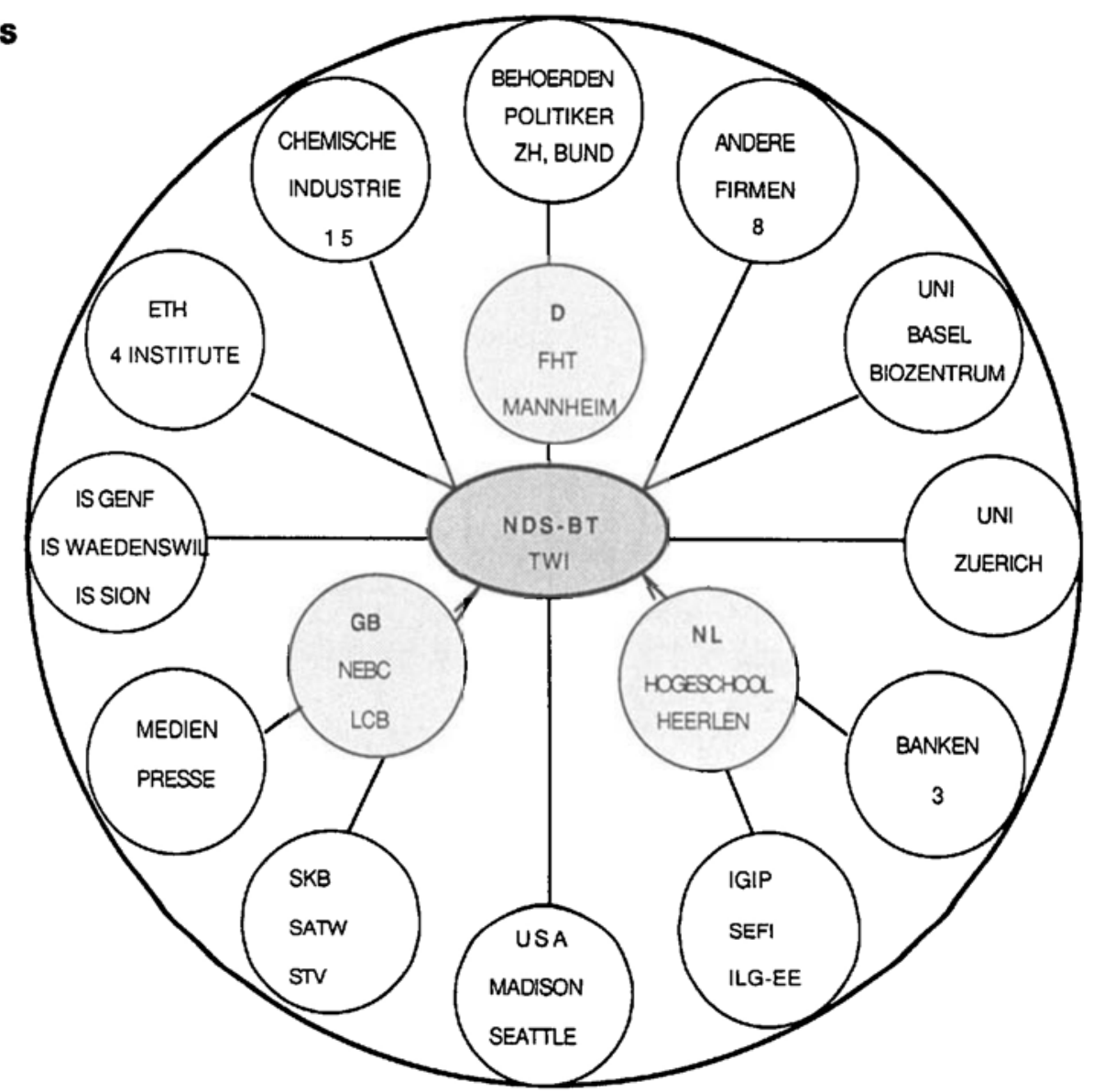

Fig. 1. Durch das Nachdiplomstudium Biotechnologie (NDS-BT) angebahnte Beziehungen des Technikums Winterthur Ingenieurschule (TWI).

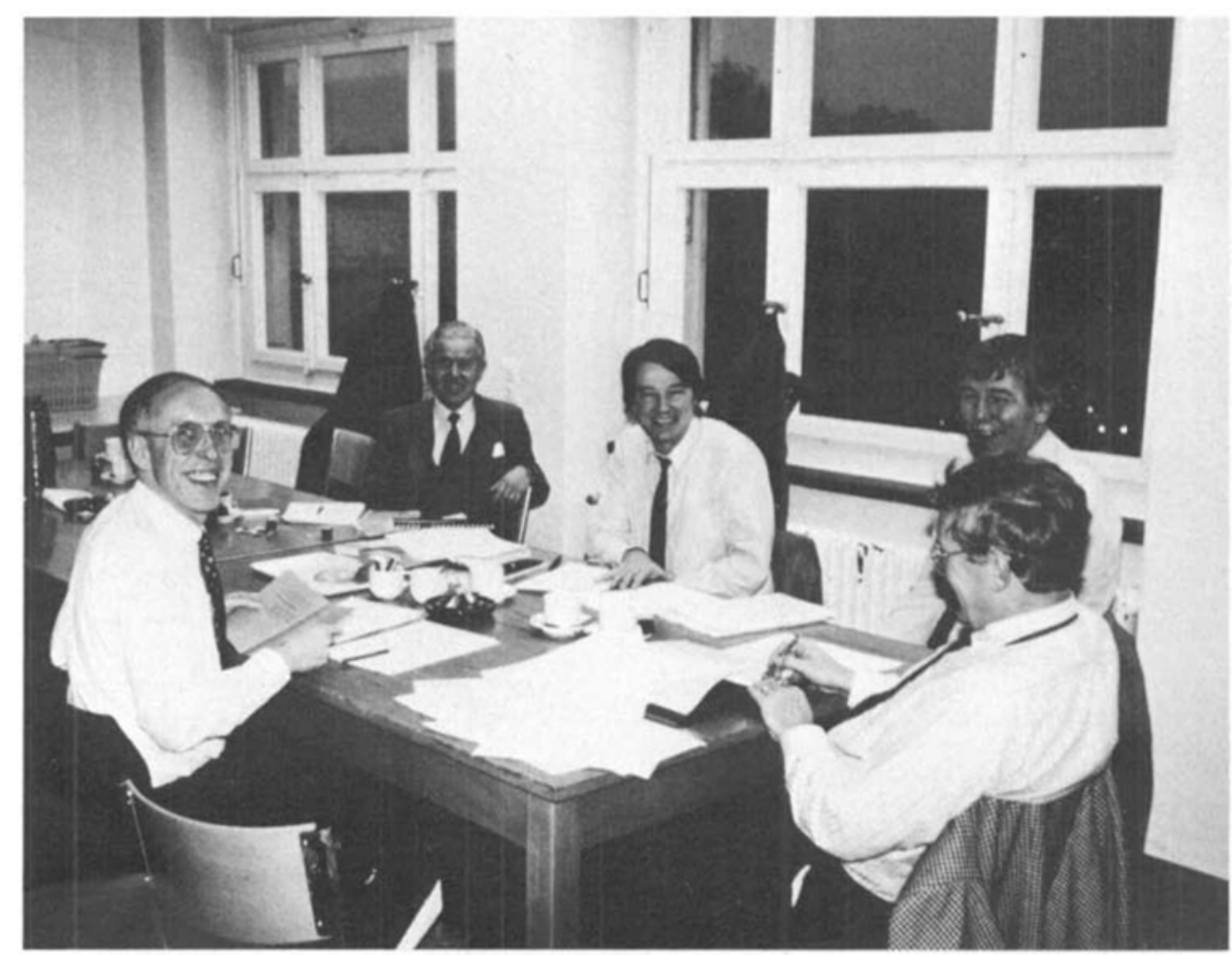

Fig. 2. Vertreter der Partnerschulen aus Deutschland, England und Holland bei Verhandlungen in Winterthur am 6./7. Dezember 1989.

tik, Umweltanalytik);

- Umweltbiotechnologie (Abwasserreinigung, Abfallbeseitigung, Abluftreinigung);

Mikrobiologie (Isolierung, Screening und Stammhaltung von Mikroorganismen);

Zellkulturtechnik (Züchtung von Zellen in spezielten Bioreaktoren).
Das NDS-BT wird geleitet vom Abteilungsvorstand der Chemieabteilung unter Mithilfe von drei hauptamtlichen Dozenten $(U$. Michel, G. Peter, H. Winzeler). Damit wird garantiert, dass die Ausbildung mindestens den Standard der Chemieausbildung am TWI erhält. Darüber hinaus beteiligen sich mehr als 30 Fachleute mit Rang und Namen aus allen wichtigen 
Biotechnologie-Schulen (z. B. ETH Zürich, Uni Zürich, Biozentrum Uni Basel) und Industrie (z. B. CibaGeigy, Sundoz, Hoffmann-La Roche, Cilag, Sulzer, Motor Columbus, Mibelle, Pharmacia etc.). Um Investitionskosten in Millionenhöhe zu sparen, findet das Bioreaktionstcchnische Praktikum bei Prof. A. Fiechter, ETH-Hönggerberg, statt und ein Teil des Aufarbeitungstechnischen Praktikums bei der Firma Pharmacia $A G$ in Freiburg im Breisgau.

Vorbildung und Aufbau des NDS-BT: Basis ist ein Diplom in Chemie oder eine äquivalente Vorbildung (bei Bedarf werden individuelle Vorkurse angeboten). Es handelt sich um ein zweisemestriges Studium mit 30 Wochenstunden und 12 Studienplätzen. Im ersten Semester werden die Grundlagen vermittelt (das Verhältnis der Theoriefächer zu Praktikum beträgt ca. 1:1), im zweiten Semester liegt das Schwergewicht auf der praktischen Anwendung (das Verhältnis der Theoriefächer zu Praktikum beträgt ca. 1:2).

Es darf nie vergessen werden, dass nur eine erstklassige Ausbildung auf allen Stufen - sowohl an den Eidgenössischen Technischen Hochschulen und den Universitäten als auch an den Ingenieurschulen (Höheren Technischen Lehranstalten, Bereich Realisation und Anwendung) - die Qualität ermöglicht, die für unser Land zugleich Rohstoff und Kapital ist. Kürzer gesagt: Unser Kapital sind unsere Köpfe. Jährlich werden in der Schweiz ca. 3400 Ingenieurdiplome verliehen, ca. 1100 von den beiden ETH's und ca. 2300 von den Ingenieurschulen. Aus diesen Zahlen wird die Bedeutung einer zeitgemässen Ausbildung an den Ingenieurschulen klar; sie ist eine Investition in die Zukunft. Die Biotechnologie fördert und verlangt Teamfähigkeit, eine der wichtigsten Fähigkeiten eines modernen Ingenieurs.

Es handelt sich bei unserem NDS-BT nicht nur um ein Modell für die Schweiz, diese Weiterbildung auf der
Stundentafel für das zweisemestrige Nachdiplomstudium Biotechnologie

\begin{tabular}{|c|c|c|}
\hline Fach & 1. Sem. & 2. Sem. \\
\hline Zellbiologie & 3 & \\
\hline Mikrobiologie & 4 & \\
\hline Mikrobiologisches Praktikum & 4 & \\
\hline Molekulargenetik & 2 & 4 \\
\hline Molekulargenetisches Praktikum & 1 & 2 \\
\hline \multicolumn{3}{|l|}{ Biochemische und Biophysikalische } \\
\hline Grundlagen, Analytik & 4 & \\
\hline Biochemisches Praktikum I & 8 & \\
\hline Biochemisches Praktikum II & & 4 \\
\hline \multicolumn{3}{|l|}{ Biotechnologische Prozesse } \\
\hline und Umwelttechnik & 1 & 2 \\
\hline Qualitätssicherung und Biosicherheit & & 1 \\
\hline Bioreaktionstechnik & 1 & 2 \\
\hline Prozessleittechnik & & 1 \\
\hline Bioreaktionstechnisches Praktikum & & 6 \\
\hline Aufarbeitungstechnik & 2 & 2 \\
\hline \multicolumn{2}{|l|}{ Aufarbeitungstechnisches Praktikum } & 6 \\
\hline Stundentote & 30 & 30 \\
\hline
\end{tabular}

Basis eines Ingenieurdiploms ist auch in Europa ein Novum und ist auf reges Interesse in Deutschland Holland und England gestossen. Am 31. Oktober 198 wurde ein Partnerschaftsabkommen mit sieben Schulen aus diesen Ländern unterzeichnet, das die gemeinsame Durchführung eines europäischen Aufbaustudiums Biotechnologie mit dem Lehrplan aus Winterthur als Basis vorsieht. Durch das gemeinsame Projekt (Fig. 2) ist das TWI als erste Schweizer Schule auch an einem ERASMUS-Antrag beteiligt - unterwegs nach dem Motto von Pasteur: "La chance sourit aux esprits préparés».

Das Nachdiplomstudium ist auf fünf Jahre beschränkt. In dieser Zeit sollte es möglich sein, eine

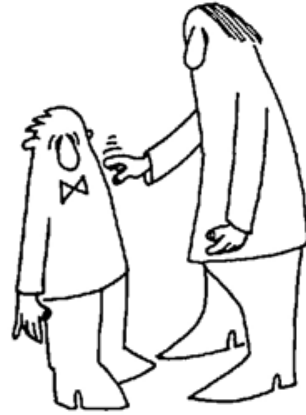

klopfen Sie uns nicht nur auf die Schultern...........

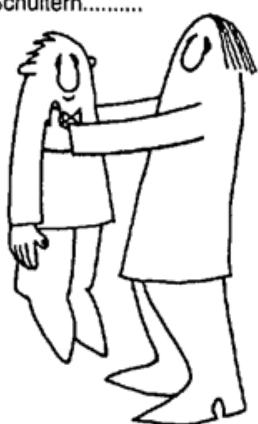

greifen Sie uns kräftig unter die Arme!

Fachrichtung "Biotechnologie» aufzubauen. Heute fehlt eine Weiterbildungsmöglichkeit für Biolaboranten/innen. Diese Lücke wäre dann geschlossen und ein ungenütztes Potential erschlossen.

Gaston Wolf

\section{Mitteilungen des Schweizerischen Komitees für Chemie - Comité Suisse de la Chimie (CSC)}

\section{Statistische Daten über Chemiestudierende und Einstellung von Chemikern in der Schweiz}

Schweiz bis 1981/82 stets rückläufig (Fig. 2). Ab 1982/ 83 erholte sich die Zahl der Chemiestudierenden parallel zum starken Wachstum der gesamthaft Studieren- den und erreichte 1986/87 ungefähr den Stand von 1976/77. In der gleichen Zeitspanne sank jedoch der prozentuale Anteil der Chemiestudierenden an der
Seit 1975 führt das Schweizerische Komitee für Chemie (CSC) eine Statistik über die Chemiestudierenden. Die Daten dienen Arbeitgebern zur Nachwuchspla. nung sowie Hochschulinstituten als Planungsgrundlage und Gradmesser für die Belicbtheit dieser Studienrichtung. Uber das Vorgehen und die Basis für diese Statistik wurde schon berichtet ${ }^{[1}$.

Die Statistik wurde nun für das Studienjahr 1988/ 1989 nachgeführt. Seit 1975/76 nahm die Zahl der Studienanfänger im Fach Chemie ab und erreichte 1980/81 einen Tiefststand (Fig. 1). Mit der markanten Zunahme der Studienanfänger in der Schweiz erholte sich die Zahl der Studienanfänger im Fach Chemie und kam 1983/84 wieder auf den Stand von 1975/76. Dabei sank jedoch der Anteil der Studienanfänger Chemie an der Gesamtzahl Studienanfänger von 2.60\% (1975/76) auf $2.28 \%(1983 / 84)$ und erreichte zuletzt $2.48 \%$ (1988/ $89)$. Die Abnahme des prozentualen Anteils dokumentiert deutlich das gesunkene Interesse am Chemiestudium. Verglichen mit dem Vorjahr nahmen 1988/89 die Studienanfänger Chemie um 6.1\% zu (Bundesrepublik Deutschland: $10.9 \%{ }^{[2]}$ ). Wie bei den Studienanfängern Chemie war die Zahl der Chemiestudierenden in der
Entwicklung Studienanfänger gesamt / Studienanfänger Chemie (Hochschulen Schweiz)

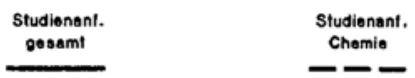

Studienanfânger $\mathrm{CH}$

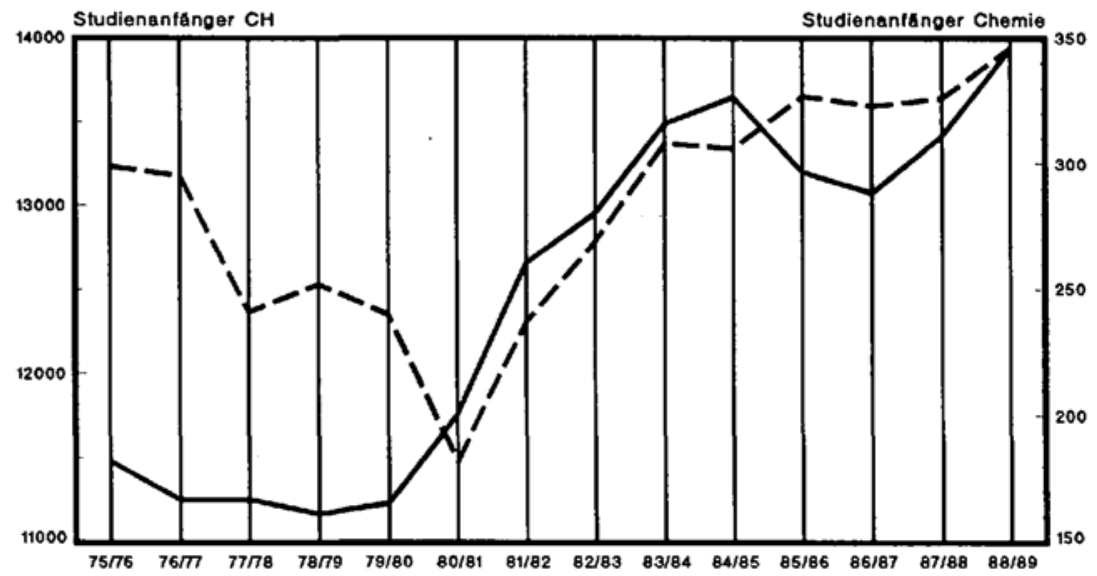

Fig. 1 
Biotechnologie-Schulen (z. B. ETH Zürich, Uni Zürich, Biozentrum Uni Basel) und Industrie (z. B. CibaGeigy, Sundoz, Hoffmann-La Roche, Cilag, Sulzer, Motor Columbus, Mibelle, Pharmacia etc.). Um Investitionskosten in Millionenhöhe zu sparen, findet das Bioreaktionstechnische Praktikum bei Prof. A. Fiechter, ETH-Hönggerberg, statt und ein Teil des Aufarbeitungstechnischen Praktikums bei der Firma Pharmacia AG in Freiburg im Breisgau.

Vorbildung und Aufbau des NDS-BT: Basis ist ein Diplom in Chemie oder eine äquivalente Vorbildung (bei Bedarf werden individuelle Vorkurse angeboten). Es handelt sich um ein zweisemestriges Studium mit 30 Wochenstunden und 12 Studienplätzen. Im ersten Semester werden die Grundlagen vermittelt (das Verhältnis der Theoriefächer zu Praktikum beträgt ca. $1: 1$ ), im zweiten Semester liegt das Schwergewicht auf der praktischen Anwendung (das Verhältnis der Theoriefächer zu Praktikum beträgt ca. 1:2).

Es darf nie vergessen werden, dass nur eine erstklassige Ausbildung auf allen Stufen - sowohl an den Eidgenössischen Technischen Hochschulen und den Universitäten als auch an den Ingenieurschulen (Höheren Technischen Lehranstalten, Bereich Realisation und Anwendung) - die Qualität ermöglicht, die für unser Land zugleich Rohstoff und Kapital ist. Kürzer gesagt: Unser Kapital sind unsere Köpfe. Jährlich werden in der Schweiz ca. 3400 Ingenieurdiplome verliehen, ca. 1100 von den beiden ETH's und ca. 2300 von den Ingenieurschulen. Aus diesen Zahlen wird die Bedeutung einer zeitgemässen Ausbildung an den Ingenieurschulen klar; sie ist eine Investition in die Zukunft. Die Biotechnologie fördert und verlangt Teamfähigkeit, eine der wichtigsten Fähigkeiten eines modernen Ingenieurs.

Es handelt sich bei unserem NDS-BT nicht nur um ein Modell für die Schweiz, diese Weiterbildung auf der
Stundentafel für das zweisemestrige Nachdiplomstudium Biotechnologie

\begin{tabular}{|c|c|c|}
\hline Fach & 1.Sem. & 2. Sem \\
\hline$\overline{\text { Zellbiologie }}$ & 3 & \\
\hline Mikrobiologie & 4 & \\
\hline Mikrobiologisches Praktikum & 4 & \\
\hline Molekulargenetik & 2 & 4 \\
\hline Molekulargenetisches Praktikum & 1 & 2 \\
\hline \multicolumn{3}{|l|}{ Biochemische und Biophysikalische } \\
\hline Grundlagen, Analytik & 4 & \\
\hline Biochemisches Praktikum I & 8 & \\
\hline Biochemisches Praktikum II & & 4 \\
\hline \multicolumn{3}{|l|}{ Biotechnologische Prozesse } \\
\hline und Umwelttechnik & 1 & 2 \\
\hline Qualitätssicherung und Biosicherheit & & 1 \\
\hline Bioreaktionstechnik & 1 & 2 \\
\hline Prozessleittechnik & & 1 \\
\hline Bioreaktionstechnisches Praktikum & & 6 \\
\hline Aufarbeitungstechnik & 2 & 2 \\
\hline \multicolumn{2}{|l|}{ Aufarbeitungstechnisches Praktikum } & 6 \\
\hline Stundentotal & 30 & 30 \\
\hline
\end{tabular}

Basis eines Ingenieurdiploms ist auch in Europa ein Novum und ist auf reges Interesse in Deutschland, Holland und England gestossen. Am 31. Oktober 1989 wurde ein Partnerschaftsabkommen mit sieben Schulen aus diesen Ländern unterzeichnet, das die gemeinsame Durchführung eines europäischen Aufbaustudiums Biotechnologie mit dem Lehrplan aus Winterthur als Basis vorsieht. Durch das gemeinsame Projekt (Fig. 2) ist das TWI als erste Schweizer Schule auch an einem ERASMUS-Antrag beteiligt - unterwegs nach dem Motto von Pasteur: "La chance sourit aux esprits préparés».

Das Nachdiplomstudium ist auf fünf Jahre beschränkt. In dieser Zeit sollte es möglich sein, eine

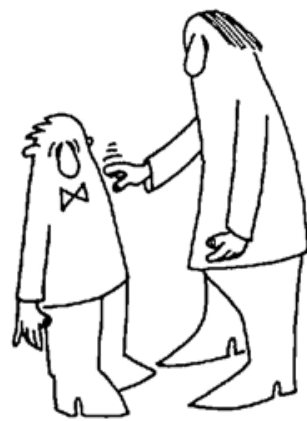

klopfen Sie uns nicht nur auf die Schultern..........

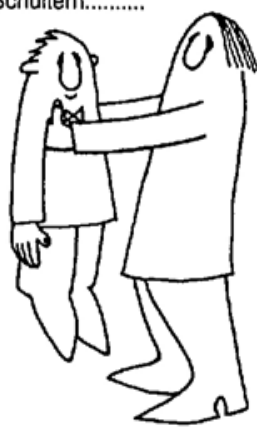

greifen Sie uns kräftig unter die Arme!

Fachrichtung «Biotechnologie» aufzubauen. Heute fehlt eine Weiterbildungsmöglichkeit für Biolaboranten/innen. Diese Lücke wäre dann geschlossen und ein ungenütztes Potential erschlossen.

Gaston Wolf

\section{Mitteilungen des Schweizerischen Komitees für Chemie - Comité Suisse de la Chimie (CSC)}

\section{Statistische Daten über Chemiestudierende und Einstellung von Chemikern in der Schweiz}

Seit 1975 führt das Schweizerische Komitee für Chemie (CSC) eine Statistik über die Chemiestudierenden. Die Daten dienen Arbeitgebern zur Nachwuchsplanung sowie Hochschulinstituten als Planungsgrundlage und Gradmesser für die Belicbtheit dieser Studienrichtung. U'ber das Vorgehen und die Basis für diese Statistik wurde schon berichtet ${ }^{[1]}$

Die Statistik wurde nun für das Studienjahr 1988/ 1989 nachgeführt. Seit 1975/76 nahm die Zahl der Studienanfänger im Fach Chemie ab und erreichte 1980/81 einen Tiefststand (Fig. 1). Mit der markanten Zunahme der Studienanfänger in der Schweiz erholte sich die Zahl der Studienanfänger im Fach Chemie und kam 1983/84 wieder auf den Stand von 1975/76. Dabei sank jedoch der Anteil der Studienanfänger Chemic an der Gesamtzahl Studienanfänger von $2.60 \%(1975 / 76)$ auf $2.28 \%(1983 / 84)$ und erreichte zuletzt $2.48 \%$ (1988/ 89). Die Abnahme des prozentualen Anteils dokumentiert deutlich das gesunkene Interesse am Chemiestudium. Verglichen mit dem Vorjahr nahmen 1988/89 die Studienanfänger Chemie um $6.1 \%$ zu (Bundesrepublik Deutschland: $\left.10.9 \%^{[2]}\right)$. Wie bei den Studienanfängern Chemie war die Zahl der Chemiestudierenden in der
Schweiz bis 1981/82 stets rückläufig (Fig. 2). Ab 1982 83 erholte sich die Zahl der Chemiestudierenden parallel zum starken Wachstum der gesamthaft Studieren-

den und erreichte 1986/87 ungefähr den Stand von 1976/77. In der gleichen Zeitspanne sank jedoch der prozentuale Anteil der Chemiestudierenden an der

\section{Entwicklung Studienanfänger gesamt / Studienanfänger Chemie} (Hochschulen Schweiz)

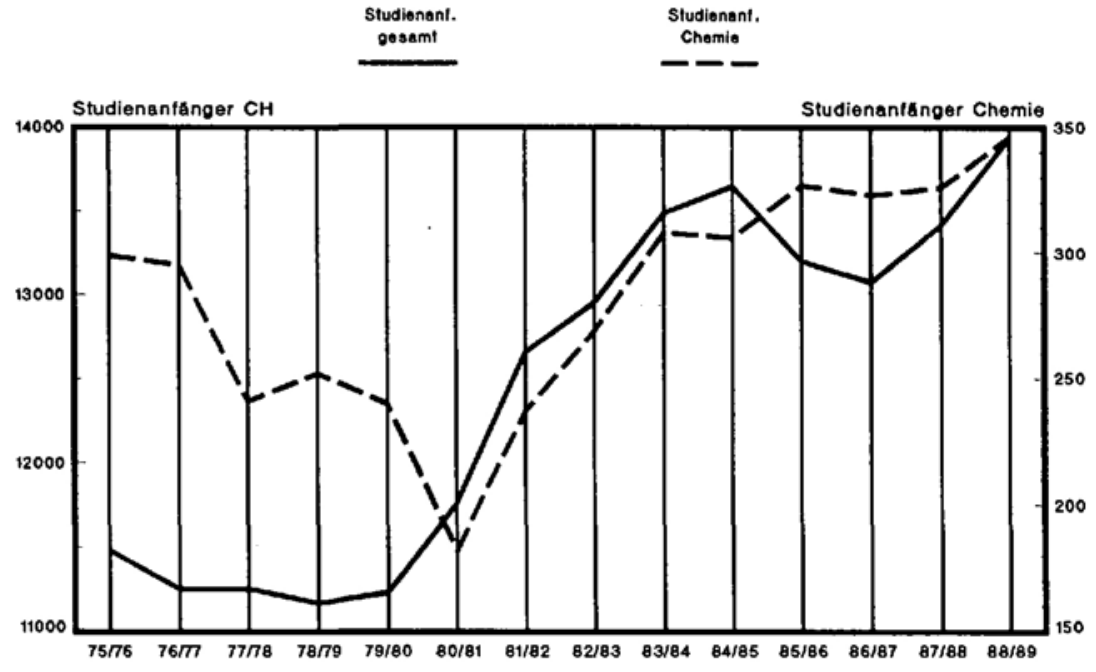

Fig. 1 


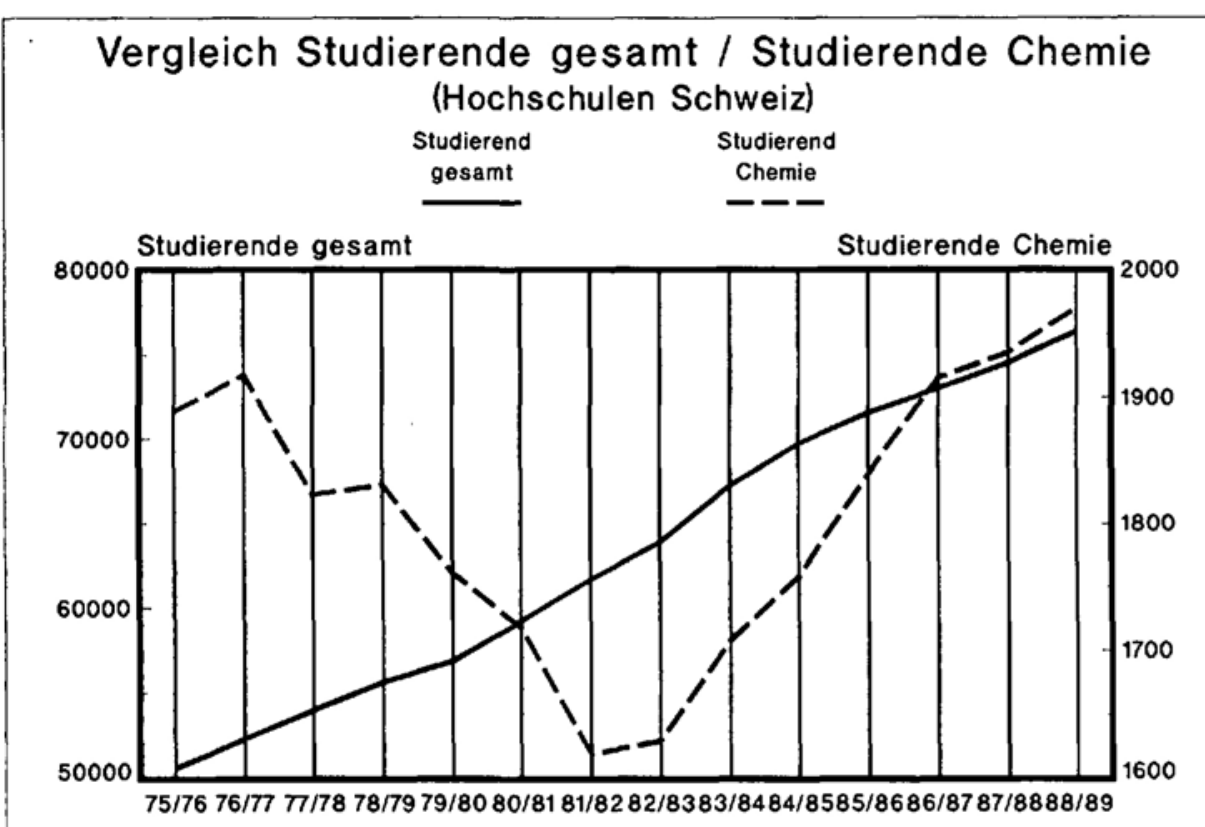

Fig. 2
$\%$ Anteil

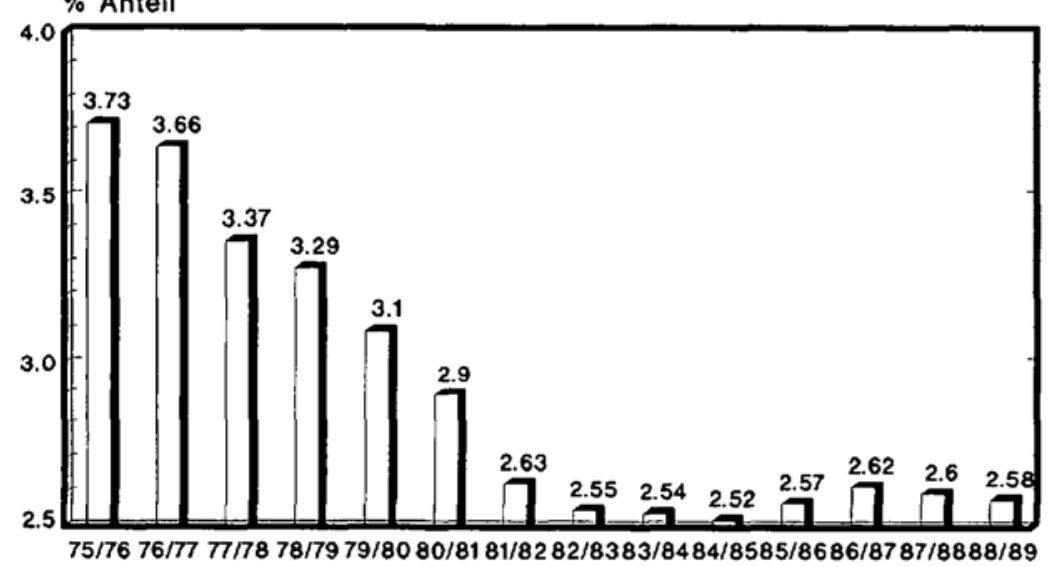

Fig. 3

Verteilung Studierende Chemie Hochschulen Schweiz (Studienjahr 88/89)

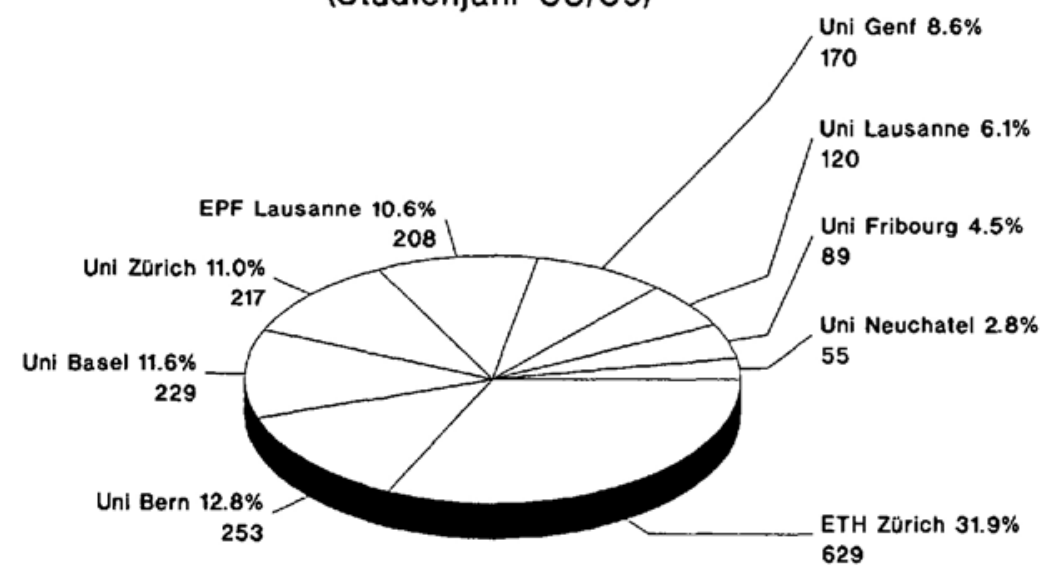

Fig. 4
Gesamtzahl Studierender von 3.73\% (1975/76) auf $2.52 \%$ (1984/85). Im Studienjahr 1988/89 stieg dieser Anteil geringfügig auf $2.58 \%$ (Fig. 3). Verglichen mit dem Vorjahr nahmen 1988/89 dic Chemiestudierenden um $1.76 \%$ zu (Bundesrepublik Deutschland: $5.5 \%{ }^{[2]}$ ). Die Verteilung der Chemiestudierenden auf die Hochschulen der Schweiz ist in Fig. 4 dargestellt: Fast ein Drittel wird an der ETH Zürich ausgebildet, dahinter folgen die Universitäten Bern (12.8\%), Basel $(11.6 \%)$ und Zürich (11.0\%) sowie die EPF Lausanne (10.6\%).

Im Auftrag der Kommission für den Chemikernach. wuchs der Schweizerischen Gesellschaft für Chemische Industrie (SGCI) wurde im Sommer 1988 eine Firmenumfrage über die in den Jahren 1983-1988 erfolgten Einstellungen von Hochschulchemikern durchgeführt. Die Umfrage wurde erfreulicherweise von 106 Firmen beantwortet. Die Auswertung ergab, dass von den 1207 in diesen Unternehmen eingestellten Hochschulchemikern $48.6 \%$ Ausländer (587) und $51.4 \%$ Schweizer waren (Fig. 5). Von den neueingestellten Hochschulchemikern traten $41.2 \%$ in Forschung und Entwicklung ein, $24.7 \%$ in "Verschiedenes», $12.7 \%$ in Management-Funktionen, $12.7 \%$ in die Produktion und $8.8 \%$ in Analytik (Fig. 6). Der grösste Ausländeranteil entfällt auf "Verschiedenes" $(53.69 \%)$, gefolgt von Forschung und Entwicklung $(50.50 \%)$, Management $(48.37 \%)$, Produktion $(43.17 \%)$ und Analytik $(36.36 \%)$. Überraschend ist der kleinste Ausländeranteil bei den Analytikern, obschon öfters die mangelnde Tradition der analytischen Ausbildung an den Schweizerischen Hochschulen beklagt wird.

Gemäss der CSC-Statistik promovieren durchschnittlich 132 Chemiker pro Jahr, in einer fünfjährigen Periode demnach 660 . Gemäss der SGCI-Umfrage wurden 1983-1988 620 Schweizer Chemiker, vorwiegend mit Promotion, eingestellt. Unter Berücksichtigung der Tatsache, dass Hochschulchemiker auch ausserhalb von chemischen Industrien benötigt werden, ist der Chemiker deshalb nach wie vor ein Mangelberuf in der Schweiz. Es ist eine dringende Aufgabe, mehr Mittelschüler für das Chemiestudium zu begeistern und zu gewinnen.

Urban Grunz (Informationsstelle CSC)

\section{Mitteilungen der}

Schweizerischen

Chemischen Gesellschaft (SCG)

Protokoll der Herbstversammlung der SCG vom 20. Oktober 1989 in Bern

\section{A. Geschäftlicher Teil}

Der Präsident, Prof. A. Eschenmoser, eröffnete die Sitzung um 9.15 Uhr.

1. Das Protokoll der Frühjahrsversammlung vom 17. März 1989 in Zürich wurde genehmigt.

2. Die Frühjahrsversammlung 1990 wird am 16. März an der ETH Zürich durchgeführt werden. Zum Thema "Trends in Organic Chemistry" werden Prof. J. Rebek (MIT), Prof. S.L. Schreiber (Harvard Univ.), Prof. P.G. Schultz (Univ. of California, Berkeley) und Prof. J.-M. Lehn (Univ. Strasbourg) vortragen; an den beiden vorhergehenden Tagen veranstaltet die Schweizerische Gesellschaft für Kristallographie ein Symposium aus Anlass des Rücktritts von Prof. J.D. Dunitz (ETH Zürich).

3. Die allen Mitgliedern mit der Einladung zugesandten Änderungen von Art. 3 und Art. 21 der Statuten werden einstimmig angenommen.

4. Die Erhöhung der Mitgliedsbeiträge für 1990 um sFr. 10.- auf sFr. 50.- für ordentliche Mitglieder und der persönlichen Abonnemente der Helv. Chim. Acta um sFr. 10.- auf sFr. 80.- wird genehmigt. 


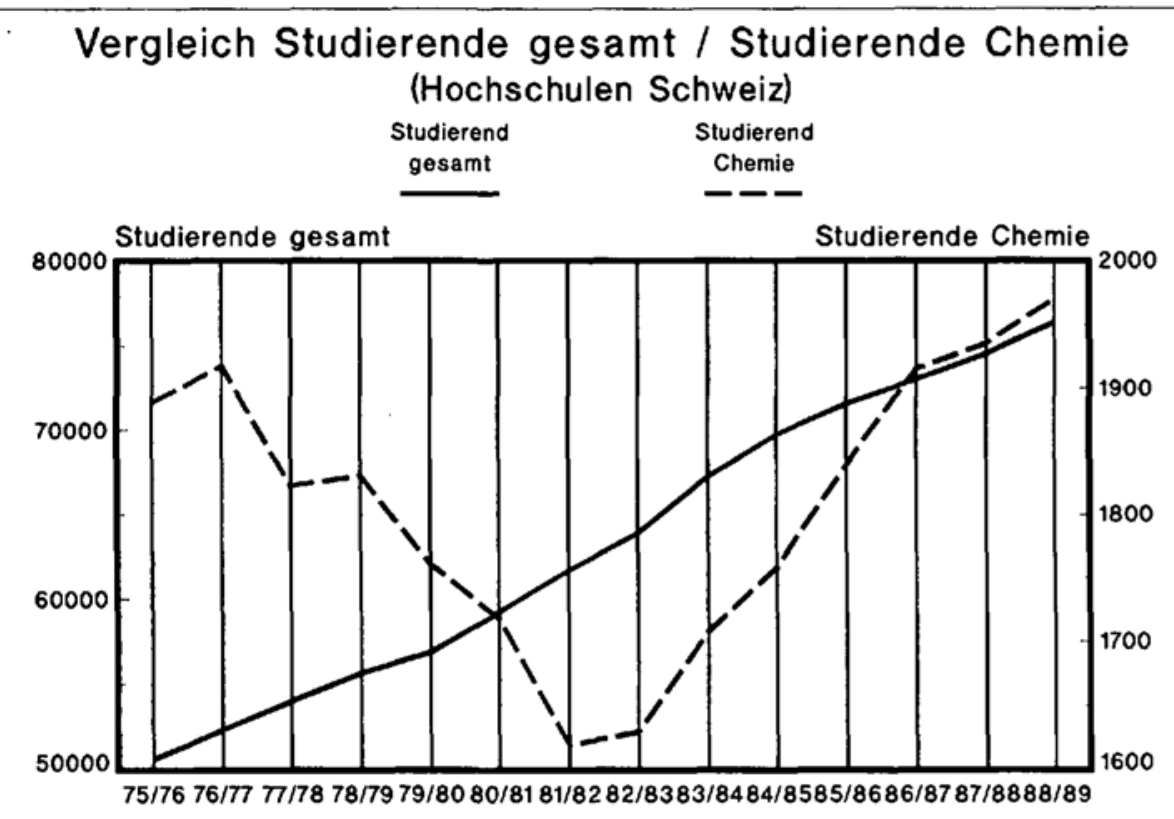

Fig. 2

\section{Anteil Chemiestudierende an Studierenden gesamt (Hochschulen Schweiz)}

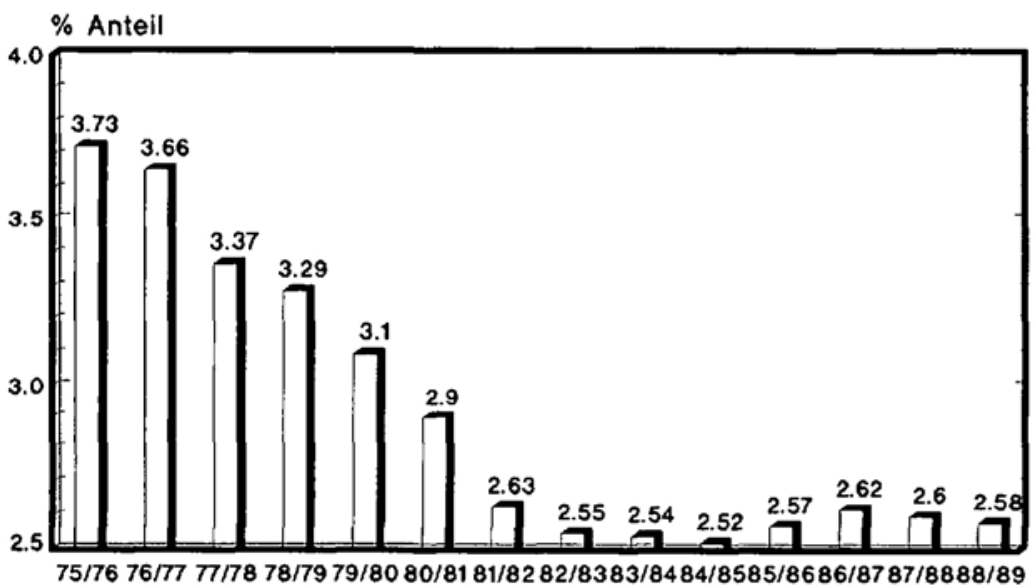

Fig. 3

\section{Verteilung Studierende Chemie Hochschulen Schweiz} (Studienjahr 88/89)

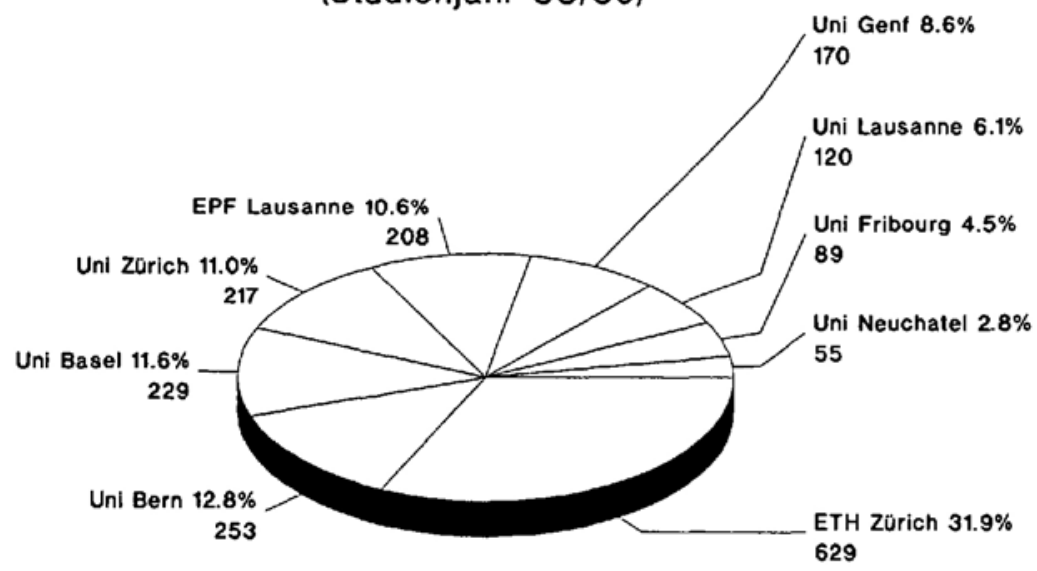

Fig. 4
Gesamtzahl Studierender von 3.73\% (1975/76) auf $2.52 \%$ (1984/85). Im Studienjahr 1988/89 stieg dieser Anteil geringfügig auf $2.58 \%$ (Fig.3). Verglichen mit dem Vorjahr nahmen 1988/89 dic Chemiestudierenden um $1.76 \%$ zu (Bundesrepublik Deutschland: $5.5 \%{ }^{[2]}$ ). Die Verteilung der Chemiestudierenden auf die Hochschulen der Schweiz ist in Fig. 4 dargestellt: Fast ein Drittel wird an der ETH Zürich ausgebildet, dahinter folgen die Universitäten Bern (12.8\%), Basel $(11.6 \%)$ und Zürich (11.0\%) sowie die EPF Lausanne (10.6\%).

Im Auftrag der Kommission für den Chemikernachwuchs der Schweizerischen Gesellschaft für Chemische Industrie (SGCI) wurde im Sommer 1988 eine Firmenumfrage über die in den Jahren 1983-1988 erfolgten Einstellungen von Hochschulchemikern durchgeführt. Die Umfrage wurde erfreulicherweise von 106 Firmen beantwortet. Die Auswertung ergab, dass von den 1207 in diesen Unternehmen eingestellten Hochschulchemikern $48.6 \%$ Ausländer (587) und $51.4 \%$ Schweizer waren (Fig. 5). Von den neueingestellten Hochschulchemikern traten $41.2 \%$ in Forschung und Entwicklung ein, $24.7 \%$ in "Verschiedenes", $12.7 \%$ in Management-Funktionen, $12.7 \%$ in die Produktion und $8.8 \%$ in Analytik (Fig. 6). Der grösste Ausländeranteil entfällt auf "Verschiedenes» $(53.69 \%)$, gefolgt von Forschung und Entwicklung $(50.50 \%)$, Management $(48.37 \%)$, Produktion $(43.17 \%)$ und Analytik $(36.36 \%)$. Überraschend ist der kleinste Ausländeranteil bei den Analytikern, obschon öfters die mangelnde Tradition der analytischen Ausbildung an den Schweizerischen Hochschulen beklagt wird.

Gemäss der CSC-Statistik promovieren durchschnittlich 132 Chemiker pro Jahr, in einer fünfjährigen Periode demnach 660 . Gemäss der SGCI-Umfrage wurden 1983-1988 620 Schweizer Chemiker, vorwiegend mit Promotion, eingestellt. Unter Berücksichtigung der Tatsache, dass Hochschulchemiker auch ausserhalb von chemischen Industrien benötigt werden, ist der Chemiker deshalb nach wie vor ein Mangelberuf in der Schweiz. Es ist eine dringende Aufgabe, mehr Mittelschüler für das Chemiestudium zu begeistern und zu gewinnen.

Urban Grunz (Informationsstelle CSC)

\section{Mitteilungen der} Schweizerischen Chemischen Gesellschaft (SCG)

Protokoll der Herbstversammlung der SCG vom 20. Oktober 1989 in Bern

\section{A. Geschäftlicher Teil}

Der Präsident, Prof. A. Eschenmoser, eröffnete die Sitzung um 9.15 Uhr.

1. Das Protokoll der Frühjahrsversammlung vom 17. März 1989 in Zürich wurde genehmigt.

2. Die Frühjahrsversammlung 1990 wird am 16. März an der ETH Zürich durchgeführt werden. Zum Thema "Trends in Organic Chemistry" werden Prof. J. Rebek (MIT), Prof. S.L. Schreiber (Harvard Univ.), Prof. P. G. Schultz (Univ, of California, Berkeley) und Prof J.-M. Lehn (Univ. Strasbourg) vortragen; an den beiden vorhergehenden Tagen veranstaltet die Schweizerische Gesellschaft für Kristallographie ein Symposium aus Anlass des Rücktritts von Prof. J.D. Dunitz (ETH Zürich).

3. Die allen Mitgliedern mit der Einladung zugesandten Änderungen von Art. 3 und Art.21 der Statuten werden einstimmig angenommen.

4. Die Erhöhung der Mitgliedsbeiträge für 1990 um sFr. 10.- auf sFr. 50.- für ordentliche Mitglieder und der persönlichen Abonnemente der Helv.Chim. Acta um sFr. 10.- auf sFr. 80.- wird genehmigt. 


\section{Einstellung Hochschulchemiker in der Schweiz (1983-1988)}

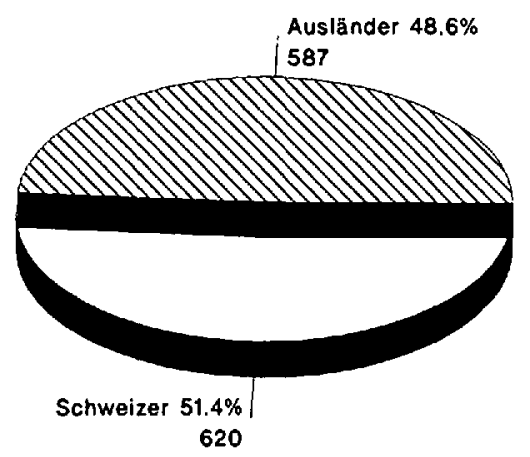

Fig. 5
Fig. 6

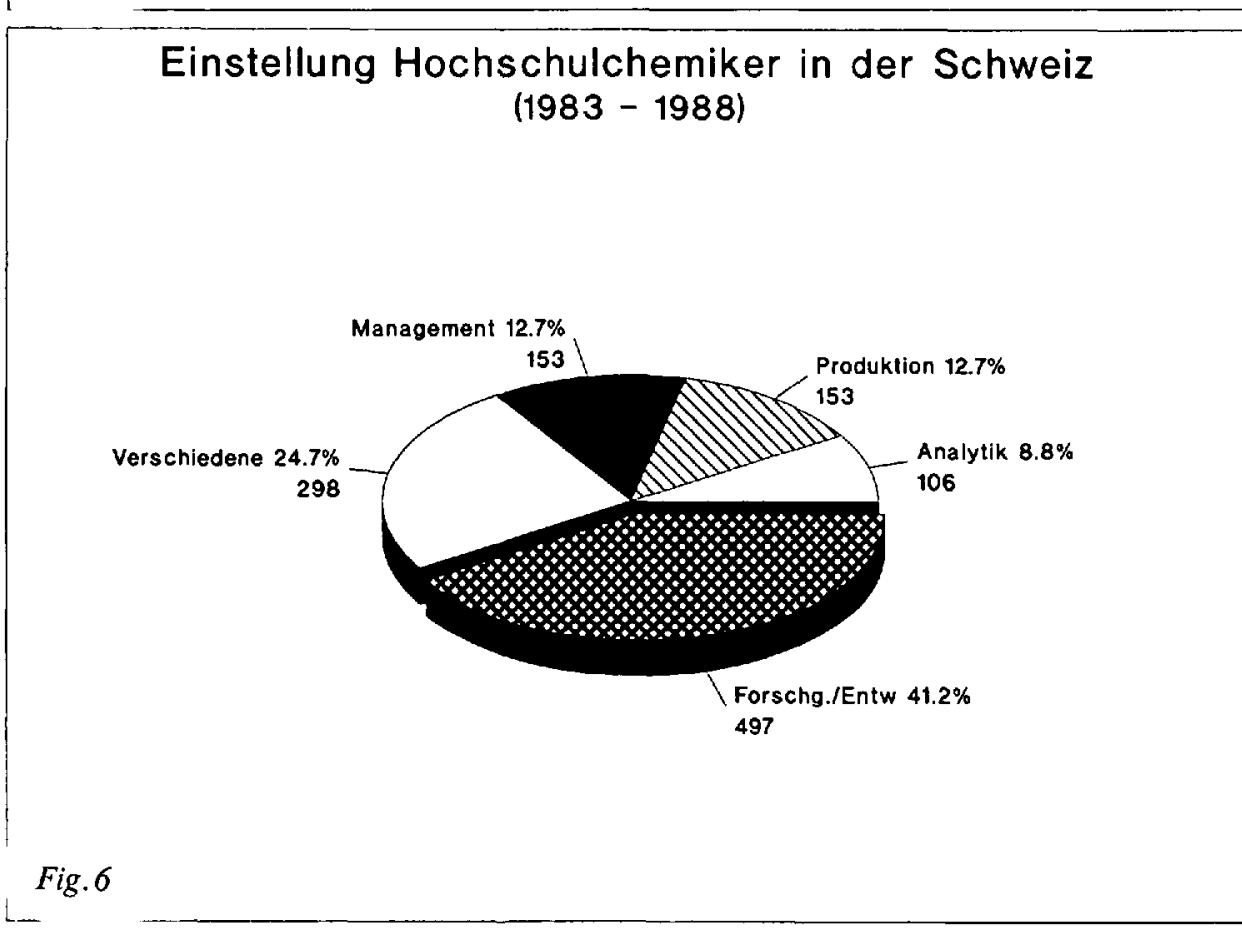

\section{Einstellung Hochschulchemiker in der Schweiz (1983 - 1988)} L-

5. Wahlen für Amtsperiode 1990-92. Als Präsident wird Prof. W. von Philipsborn (Univ. Zürich), als Vizepräsident Prof. A.E. Merbach (Univ. Lausanne) gewāhlt. Neu als Beisitzer in den Vorstand gewählt wird Dr. $K$. Mïller (Hoffmann-La Roche, Basel), ohne Gegenstimme bestätigt für weitere zwei Jahre werden die bisherigen Beisitzer Dr. D. Bellus (Ciba-Geigy, Basel) und Prof. D. Seebach (ETH Zürich) sowie Dr. P. Zeller (Basel) als Rechnungsrevisor.

Damit setzt sich der Vorstand für 1990-92 wie folgt zusammen:

Präsident: W. von Philipsborn, Zürich

Vizepräsident: A. E. Merbach, Lausanne

Schatzmeister: J. Kalvoda, Basel

Altpräsidenten: T. Gäumann, Lausanne; G. Ohloff, Genf; A. Eschenmoser, Zürich

Beisitzer: D. Hauser, Basel; D. Bellus, Basel; K. Müller, Basel; D. Seebach, Zürich

Vertreter des Redaktionskomitees Helvetica Chimica Acta: E. Heilbronner, Herrliberg; L. M. Venanzi, Zürich; H. J. Hansen, Zürich; C. Tamm, Basel

Redaktor Helv. Chim. Acta: M. V. Kisakürek, Basel

Rechnungsrevisoren: J. Wirz, Basel; P. Zeller, Basel

Sekretär: E Zass, Zürich
Das Redaktionskomitee Helvetica Chimica Acta hat folgende Mitglieder:

Präsident: E. Heilbronner, Herrliberg

Vizepräsidenten: L. M. Venanzi, Zürich; H.J. Hansen, Zürich; C. Tamm, Basel

Beisitzer: H. B. Bürgi, Bern; H.-F. Eicke, Basel; H. Heimgartner, Zürich; M. Hesse, Zürich; A.E. Merbach, Lausanne; K. Müller, Basel; W. Oppolzer, Genf; R. Scheffold, Bern; D. Seebach, Zürich; B. Testa, Lausanne; A. Vasella, Zürich; J. Wirz, Basel

Redaktoren: M.V. Kisakürek, Basel; G. Gescheidt, Basel

6. Die schriftliche Abstimmung zur Kooperation Schweizerische Chemische Gesellschafi/Schweizerischer Chemiker-Verband ergab 562 Ja- und 10 Nein-Stimmen (Stimmbeteiligung $36.5 \%$ ). Der Präsident erläutert das Ergebnis, verliest einige der eingegangenen Kommentare und teilt mit, dass aufgrund der Abstimmung nun die Koordinationskommission zusammentreten wird, in die der Vorstand als Vertreter der SCG Prof. Merbach und Prof. von Philipsborn gewählt hat. Die Mitglieder werden laufend über Fortschritte informiert werden. Fragen aus der Versammlung zu diesem
Thema betreffen einen Zusamnmenschluss aller chemischen Gesellschaften in der Schweiz und eine Zeitschrift zur Information der Mitglieder wie bei der Gesellschaft Deutscher Chemiker; zum ersten wird gesagt, dass dies ein erstrebenswertes Endziel sei, zuerst aber die beiden grössten Geseltschaften fusionieren würden, als Mitteilungsblatt wird die Chimia dienen.

7. Varia: Keine Wortmeldung.

Schluss der Sitzung: 8.55 Uhr.

\section{B. Wissenschaftlicher Teil}

Das Programm enthielt den Vortrag des Werner-Preisträgers 1989, PD Dr. A. Pfaltz (ETH Zürich) «Von Corrin- und Hydrocorphin-Metallkomplexen zu massgeschneiderten Katalysatoren für die asymmetrische Synthese», das Symposium "Inorganic and Coordination Chemistry: Role of Surfaces» mit den Vorträgen von $H$. Schmid (Université de Genève) «Applications of Polarised Light Microscopy for Characterisation of Old and New Materials», P.P. Edwards (University of Cambridge/U. K.) "Superconductivity and the Chemical Bond, L.J. Gauckler (ETH Zürich) «The Development of Structural Ceramics" und M.L.H. Green (University of Oxford/U.K.) "Uses of Organometallic Compounds in Materials Science», in zwei parallelen Vormittags- und drei parallelen Nachmittags-Sitzungen insgesamt 44 Kurzmitteilungen der Sektion Organische Chemie, Hauptvorträge von C.R. Ganellin (University College London/U. K.) «Designing Drugs for Histamine Receptors's und $B$. Testa (Université de Lausanne) (Mechanisms of Chiral Recognition in Pharmacokinetic and Pharmacodynamic Processes" sowie 10 Kurzmitteilungen der Sektion Medizinische Chemie, Kurzmitteilungen in den Sektionen Physikalische Chemie (5), Radiochemie (7), im Minisymposium "Computational Chemistry» (4), 60 Poster der Sektion Anorganische und Koordinationschemie sowie eine Demonstration von Unterrichts-Software für Personal-Computer der (Study Group on Computer Assisted Teaching' der Kommission für Unterrichtsfragen im Schweizerischen Komitee für Chemie.

Der Präsident:

Prof. A. Eschenmoser

Der Sekretär:

Dr. E. Zass

\section{Werner-Preis}

Der Vorstand teilt den Mitgliedern der Schweizerischen Chemischen Gesellschaft mit, dass dieser Preis an der Frühjahrsversammlung 1991 nach den Bestimmungen der Artikel 23-26 der Statuten verliehen werden kann:

«Der Preis mit Medaille kann in jährlichem Turnus an schweizerische oder in der Schweiz tätige, ausländische Nachwuchswissenschafter für ausgezeichnete Forschungsarbeiten auf dem Gebiete der Chemie verliehen werden. Pro Jahr werden in der Regel höchstens zwei Werner-Preise erteilt. Die Auswahl der Preisträger hat sich nicht auf Kandidaten zu beschränken, die an einer Hochschule tätig sind. Ausnahmsweise kann der Preis auch an ältere Forscher verliehen werden.?

Vorschläge und Bewerbungen sind mit den nachstehend aufgeführten Belegen dem Präsidenten der SCG bis zum 31. Mai 1990 einzureichen.

a) Antrag mit Begründung

b) Curriculum vitae

c) Publikationsliste

d) gegebenenfalls Separata ausgewählter Publikationen

Im Namen des Vorstandes

Der Präsident:

Prof. A. Eschenmoser

Laboratorium für Organische Chemie der ETH Zürich

Universitätstrasse 16

CH-8092 Zürich 


\section{Frühjahrsversammlung 1990 in Zürich}

Am Freitag, den 16. März dieses Jahres, wird die SCG-Frühjahrsversammlung an der ETH Zürich-Zentrum, Hauptgebäude, Auditorium Maximum, Rämistrasse 101, stattfinden:

\section{Trends in Organic Chemistry}

09.30 Geschäftlicher Teil

Wissenschaftlicher Teil

10.00 J.-M. Lehn (Université Louis Pasteur, Strasbourg):

"Perspektiven der supramolekularen Chemie»

II.00 Pause

11.15 Ehrungen der Schweizerischen Chemischen Gesellschaft:

Verleihung des Werner-Preises und des Paracelsus-Preises 1990

11.30 R. Breslow (Columbia University, New York): "The Chelate Effect: Binding, Catalysis, and Chemotherapy"

12.30 Mittagspause

14.30 J. Rebek, jr. (Massachusetts Institute of Technology):

"Recognition and Catalysis with Model Systems"

15.30 S. L. Schreiber (Harvard University, Cambridge, U.S.A.):

"Molecular Recognition of the Immunophilins" 16.30 Pause

16.50 P.G. Schultz (University of California, Berkeley):

"Catalytic Antibodies"

17.50 Schluss der Versammlung

Information/Kontakt:

- Dr. E. Zass, Sekretär SCC

ETĤ Zürich, Universitätstrasse 16

$\mathrm{CH}-8092$ Zürich

An den beiden vorhergehenden Tagen veranstaltet die Schweizerische Gesellschaft für Kristallographie vom 14.-15. März am gleichen Ort

\section{Chemistry and Structure}

A Symposium in Honour of Professor J.D. Dunitz

mit Vorträgen von

H.-B. Bürgi (Bern): «Reaction Rate and Geometrical Structure»

J. Bernstein (Beer-Sheva): "Polymorphism in Organic Crystals - Utilizing and Understanding the Differences"

J.D. Dunitz (Zürich): «Chemical Aspects of Phase Transitions in Molecular Crystals"

A. Gavezzotti (Milan): «The Crystal Packing of Organic Molecules - Geometry and Forces»

R. Hoffmann (Cornell): «Waiting to be Made»

\section{Frühjahrstagung der}

Polymer-Gruppe der Schweiz (PGS):

\section{Polymer-Forschung und -Entwicklung in der Industrie}

Biel/Bienne, 22. März 1990

Mit dieser Tagung im Hotel Elite setzt die PGS ihren Vortragszyklus über «Industrielle F + E-Tätigkeiten auf dem Polymer-Gebiet in der Schweiz" fort, wobei den in der Schweiz tätigen Firmen die Möglichkeit geboten wird, sich vorzustellen. An der zweiten Tagung

im Rahmen dieses Zyklus werden die Firmen:

- Asea Brown Boveri AG,

- Ciba-Geigy AG,

- Huber \& Suhner AG,

- Isola-Werke AG

über ihr Tätigkeitsgebiet berichten.

Weitere Auskünfte und Anmeldungen:

- Sekretariat der PGS am Institut für Polymere der ETH-Z

Universitätstrasse 6

CH-8092 Zürich

Tel.: (01) 2563058

Mitteilungen des

Schweizerischen

Chemiker-Verbandes (SCV)

\section{Voranzeige: Generalversammlung und Frühjahrstagung '90 des $\mathrm{SChV}$}

Die diesjährige Generalversammlung des SChV findet am 27. April 1990, um 10.30 Uhr, bei der Lonza AG in Visp/VS statt. Das Thema der gleichzeitig stattfindenden Frühjahrstagung lautet:

\section{Integrierte Entsorgung in der LONZA}

und ist abgestimmt auf die Fachtagung der Schweizerischen Vereinigung diplomierter Chemiker HTL (SVCT) mit dem Thema:

\section{Abfall-Szene Schweiz:}

\section{Vorsorge, Recycling, Entsorgung}

die am 14. März 1990 bei der Sandoz AG in Basel stattfinden wird.

Die Frühjahrstagung des SChV veranschaulicht mit Vorträgen und einer Besichtigung die praktische Durchführung von Entsorgung und Umweltschutz in der Chemischen Industrie. Reservieren Sie bitte beide Termine.

Der Vorstand SChV

\section{Neue Mitglieder}

Atallah Elias, M.Sc. Environmental Pollution Control (University of Leeds, UK), selbständiger Chemieund Umweltingenieur, Bürglistrasse 22, 8400 Winterthur.

Crevoisier Michel, Dr. phil. nat. (Universität Bern), Marchbachstrasse 11, 4107 Ettingen.

Hilfiker Rolf, Dr. phil. nat. (Universität Basel), Breisacherstrasse 68, 4057 Basel.

Matter Walter, Dr. sci. nat. (ETH Zürich), Zumhofstrasse 76,6010 Kriens.

Müller René, Dipl.Chem., Doktorand (ETH Zürich), Fürschtweg $36 \mathrm{~B}, 8880$ Walenstadt.

Wyden Horst, Chemiker HTL, Fohlenweidstrasse 35,8615 Wermatswil.

\section{Personalia}

\section{Beförderungen in der Industrie}

"Wissenschaftlicher Experte» und «Experte» sind als firmeninterne Titel (Ciba-Geigy, Hoffmann-La Roche) Auszeichnungen für wissenschaftliche bzw. andere Leistungen, deren Bedeutung einer Beförderung in den Direktorenrang entspricht.

\section{LABORATORIEN HAUSMANN AG}

Die Geschäftsleitung Hausmann/Vifor hat zum Wissenschaftlichen Experten ernannt:

Dr. Peter Geisser, Leiter der chemischen und biochemischen Forschung.

\section{Ehrungen}

Jeremy R. Knowles, Prof. für Chemie und Biochemie an der Harvard University, Cambridge, Massachusetts (USA), ist an der ETH Zürich in Anerkennung seiner grundlegenden Beiträge zur Stereochemie mit der Prelog-Medaille 1989 ausgezeichnet worden.

Dieter Seebach, Prof. für Chemie am Laboratorium für Organische Chemie der ETH Zürich, wurde von der Université Montpellier II Sciences et Techniques du Languedoc, Frankreich, der Titel Docteur honoris causa verliehen. Mit der Ehrendoktorurkunde wurde ihm die aus Anlass der 700-Jahr-Feier der Universität Montpellier (1989) geprägte Medaille überreicht.

\section{Ernennung}

Alfons Baiker, Dr., Titularprofessor und Privatdozent am Laboratorium für Technısche Chemie der ETH Zürich, wurde zum ausserordentlichen Professor ernannt.

\section{PSI Minisymposium}

\section{Elektrochemische Energiespeicherung}

\section{Bern, 8. März 1990}

Tagungsort: Universität Bern, Chemische Institutc, Freiestrasse 3, Hörsaal EG 16

\section{Programm}

\subsection{Begrüssung}

$10.20 W . A . M c R a e$, Zürich (früher Fa. Ionics, USA) "Ion Exchange Membranes I"

- brief history of synthetic ion exchange/ion selective membranes - preparation of ion exchange membranes

11.05 Diskussion

11.20 W. A. McRae

"Ion Exchange Membranes II"

- physical-chemical properties important to electrochemical applications

12.05 Diskussion

14.00 G.B. Tanny, Advanced Technology, Gelman Science Inc., USA

«Transport Selective Membranes as Battery Separators"

- separators for $\mathrm{Zn} / \mathrm{MnO}_{2}, \mathrm{Ag} / \mathrm{AgO}$, and $\mathrm{Zn} / \mathrm{HgO}$ batteries

- novel separator for lithium batteries

14.45 Diskussion

15.20 W. Böhnstedt, Grace GmbH, Battery Separator Technical Center, Norderstedt (Hamburg) «Der Einfluss des Separators auf die Antimonvergiftung in zyklisch belasteten Bleiakkumulatoren"

16.05 Diskussion

16.20 Schluss

Information/Kontakt

- Dr. G. Scherer

Paul Scherrer Institut

CH-5232 Villigen PSI

Tel.: (056) 992928 


\section{Frühjahrsversammlung 1990 in Zürich}

Am Freitag, den 16. März dieses Jahres, wird die SCG-Frühjahrsversammlung an der ETH Zürich-Zentrum, Hauptgebäude, Auditorium Maximum, Rämistrasse 101, stattfinden:

\section{Trends in Organic Chemistry}

09.30 Geschäftlicher Teil

Wissenschaftlicher Teil

10.00 J.-M. Lehn (Université Louis Pasteur, Strasbourg):

"Perspektiven der supramolekularen Chemie»

II.00 Pause

11.15 Ehrungen der Schweizerischen Chemischen Gesellschaft:

Verleihung des Werner-Preises und des Paracelsus-Preises 1990

11.30 R. Breslow (Columbia University, New York): "The Chelate Effect: Binding, Catalysis, and Chemotherapy"

12.30 Mittagspause

14.30 J. Rebek, jr. (Massachusetts Institute of Technology):

"Recognition and Catalysis with Model Systems"

15.30 S. L. Schreiber (Harvard University, Cambridge, U.S.A.):

"Molecular Recognition of the Immunophilins" 16.30 Pause

16.50 P.G. Schultz (University of California, Berkeley):

"Catalytic Antibodies"

17.50 Schluss der Versammlung

Information/Kontakt:

- Dr. E. Zass, Sekretär SCC

ETĤ Zürich, Universitätstrasse 16

$\mathrm{CH}-8092$ Zürich

An den beiden vorhergehenden Tagen veranstaltet die Schweizerische Gesellschaft für Kristallographie vom 14.-15. März am gleichen Ort

\section{Chemistry and Structure}

A Symposium in Honour of Professor J.D. Dunitz

mit Vorträgen von

H.-B. Bürgi (Bern): «Reaction Rate and Geometrical Structure»

J. Bernstein (Beer-Sheva): "Polymorphism in Organic Crystals - Utilizing and Understanding the Differences"

J.D. Dunitz (Zürich): «Chemical Aspects of Phase Transitions in Molecular Crystals"

A. Gavezzotti (Milan): «The Crystal Packing of Organic Molecules - Geometry and Forces»

R. Hoffmann (Cornell): «Waiting to be Made»

\section{Frühjahrstagung der}

Polymer-Gruppe der Schweiz (PGS):

\section{Polymer-Forschung und -Entwicklung in der Industrie}

Biel/Bienne, 22. März 1990

Mit dieser Tagung im Hotel Elite setzt die PGS ihren Vortragszyklus über «Industrielle F + E-Tätigkeiten auf dem Polymer-Gebiet in der Schweiz" fort, wobei den in der Schweiz tätigen Firmen die Möglichkeit geboten wird, sich vorzustellen. An der zweiten Tagung

im Rahmen dieses Zyklus werden die Firmen:

- Asea Brown Boveri AG,

- Ciba-Geigy AG,

- Huber \& Suhner AG,

- Isola-Werke AG

über ihr Tätigkeitsgebiet berichten.

Weitere Auskünfte und Anmeldungen:

- Sekretariat der PGS am Institut für Polymere der ETH-Z

Universitätstrasse 6

CH-8092 Zürich

Tel.: (01) 2563058

Mitteilungen des

Schweizerischen

Chemiker-Verbandes (SCV)

\section{Voranzeige: Generalversammlung und Frühjahrstagung '90 des $\mathrm{SChV}$}

Die diesjährige Generalversammlung des SChV findet am 27. April 1990, um 10.30 Uhr, bei der Lonza AG in Visp/VS statt. Das Thema der gleichzeitig stattfindenden Frühjahrstagung lautet:

\section{Integrierte Entsorgung in der LONZA}

und ist abgestimmt auf die Fachtagung der Schweizerischen Vereinigung diplomierter Chemiker HTL (SVCT) mit dem Thema:

\section{Abfall-Szene Schweiz:}

\section{Vorsorge, Recycling, Entsorgung}

die am 14. März 1990 bei der Sandoz AG in Basel stattfinden wird.

Die Frühjahrstagung des SChV veranschaulicht mit Vorträgen und einer Besichtigung die praktische Durchführung von Entsorgung und Umweltschutz in der Chemischen Industrie. Reservieren Sie bitte beide Termine.

Der Vorstand SChV

\section{Neue Mitglieder}

Atallah Elias, M.Sc. Environmental Pollution Control (University of Leeds, UK), selbständiger Chemieund Umweltingenieur, Bürglistrasse 22, 8400 Winterthur.

Crevoisier Michel, Dr. phil. nat. (Universität Bern), Marchbachstrasse 11, 4107 Ettingen.

Hilfiker Rolf, Dr. phil. nat. (Universität Basel), Breisacherstrasse 68, 4057 Basel.

Matter Walter, Dr. sci. nat. (ETH Zürich), Zumhofstrasse 76,6010 Kriens.

Müller René, Dipl.Chem., Doktorand (ETH Zürich), Fürschtweg $36 \mathrm{~B}, 8880$ Walenstadt.

Wyden Horst, Chemiker HTL, Fohlenweidstrasse 35,8615 Wermatswil.

\section{Personalia}

\section{Beförderungen in der Industrie}

"Wissenschaftlicher Experte» und «Experte» sind als firmeninterne Titel (Ciba-Geigy, Hoffmann-La Roche) Auszeichnungen für wissenschaftliche bzw. andere Leistungen, deren Bedeutung einer Beförderung in den Direktorenrang entspricht.

\section{LABORATORIEN HAUSMANN AG}

Die Geschäftsleitung Hausmann/Vifor hat zum Wissenschaftlichen Experten ernannt:

Dr. Peter Geisser, Leiter der chemischen und biochemischen Forschung.

\section{Ehrungen}

Jeremy R. Knowles, Prof. für Chemie und Biochemie an der Harvard University, Cambridge, Massachusetts (USA), ist an der ETH Zürich in Anerkennung seiner grundlegenden Beiträge zur Stereochemie mit der Prelog-Medaille 1989 ausgezeichnet worden.

Dieter Seebach, Prof. für Chemie am Laboratorium für Organische Chemie der ETH Zürich, wurde von der Université Montpellier II Sciences et Techniques du Languedoc, Frankreich, der Titel Docteur honoris causa verliehen. Mit der Ehrendoktorurkunde wurde ihm die aus Anlass der 700-Jahr-Feier der Universität Montpellier (1989) geprägte Medaille überreicht.

\section{Ernennung}

Alfons Baiker, Dr., Titularprofessor und Privatdozent am Laboratorium für Technısche Chemie der ETH Zürich, wurde zum ausserordentlichen Professor ernannt.

\section{PSI Minisymposium}

\section{Elektrochemische Energiespeicherung}

\section{Bern, 8. März 1990}

Tagungsort: Universität Bern, Chemische Institutc, Freiestrasse 3, Hörsaal EG 16

\section{Programm}

\subsection{Begrüssung}

$10.20 W . A . M c R a e$, Zürich (früher Fa. Ionics, USA) "Ion Exchange Membranes I"

- brief history of synthetic ion exchange/ion selective membranes - preparation of ion exchange membranes

11.05 Diskussion

11.20 W. A. McRae

"Ion Exchange Membranes II"

- physical-chemical properties important to electrochemical applications

12.05 Diskussion

14.00 G.B. Tanny, Advanced Technology, Gelman Science Inc., USA

«Transport Selective Membranes as Battery Separators"

- separators for $\mathrm{Zn} / \mathrm{MnO}_{2}, \mathrm{Ag} / \mathrm{AgO}$, and $\mathrm{Zn} / \mathrm{HgO}$ batteries

- novel separator for lithium batteries

14.45 Diskussion

15.20 W. Böhnstedt, Grace GmbH, Battery Separator Technical Center, Norderstedt (Hamburg) «Der Einfluss des Separators auf die Antimonvergiftung in zyklisch belasteten Bleiakkumulatoren"

16.05 Diskussion

16.20 Schluss

Information/Kontakt

- Dr. G. Scherer

Paul Scherrer Institut

CH-5232 Villigen PSI

Tel.: (056) 992928 


\section{Frühjahrsversammlung 1990 in Zürich}

Am Freitag, den 16. März dieses Jahres, wird die SCG-Frühjahrsversammlung an der ETH Zürich-Zentrum, Hauptgebäude, Auditorium Maximum, Rämistrasse 101, stattfinden:

\section{Trends in Organic Chemistry}

09.30 Geschäftlicher Teil

Wissenschaftlicher Teil

10.00 J.-M. Lehn (Université Louis Pasteur, Strasbourg):

"Perspektiven der supramolekularen Chemie»

II.00 Pause

11.15 Ehrungen der Schweizerischen Chemischen Gesellschaft:

Verleihung des Werner-Preises und des Paracelsus-Preises 1990

11.30 R. Breslow (Columbia University, New York): "The Chelate Effect: Binding, Catalysis, and Chemotherapy"

12.30 Mittagspause

14.30 J. Rebek, jr. (Massachusetts Institute of Technology):

"Recognition and Catalysis with Model Systems"

15.30 S. L. Schreiber (Harvard University, Cambridge, U.S.A.):

"Molecular Recognition of the Immunophilins" 16.30 Pause

16.50 P.G. Schultz (University of California, Berkeley):

"Catalytic Antibodies"

17.50 Schluss der Versammlung

Information/Kontakt:

- Dr. E. Zass, Sekretär SCC

ETĤ Zürich, Universitätstrasse 16

$\mathrm{CH}-8092$ Zürich

An den beiden vorhergehenden Tagen veranstaltet die Schweizerische Gesellschaft für Kristallographie vom 14.-15. März am gleichen Ort

\section{Chemistry and Structure}

A Symposium in Honour of Professor J.D. Dunitz

mit Vorträgen von

H.-B. Bürgi (Bern): «Reaction Rate and Geometrical Structure»

J. Bernstein (Beer-Sheva): "Polymorphism in Organic Crystals - Utilizing and Understanding the Differences"

J.D. Dunitz (Zürich): «Chemical Aspects of Phase Transitions in Molecular Crystals"

A. Gavezzotti (Milan): «The Crystal Packing of Organic Molecules - Geometry and Forces»

R. Hoffmann (Cornell): «Waiting to be Made»

\section{Frühjahrstagung der}

Polymer-Gruppe der Schweiz (PGS):

\section{Polymer-Forschung und -Entwicklung in der Industrie}

Biel/Bienne, 22. März 1990

Mit dieser Tagung im Hotel Elite setzt die PGS ihren Vortragszyklus über «Industrielle F + E-Tätigkeiten auf dem Polymer-Gebiet in der Schweiz" fort, wobei den in der Schweiz tätigen Firmen die Möglichkeit geboten wird, sich vorzustellen. An der zweiten Tagung

im Rahmen dieses Zyklus werden die Firmen:

- Asea Brown Boveri AG,

- Ciba-Geigy AG,

- Huber \& Suhner AG,

- Isola-Werke AG

über ihr Tätigkeitsgebiet berichten.

Weitere Auskünfte und Anmeldungen:

- Sekretariat der PGS am Institut für Polymere der ETH-Z

Universitätstrasse 6

CH-8092 Zürich

Tel.: (01) 2563058

Mitteilungen des

Schweizerischen

Chemiker-Verbandes (SCV)

\section{Voranzeige: Generalversammlung und Frühjahrstagung '90 des $\mathrm{SChV}$}

Die diesjährige Generalversammlung des SChV findet am 27. April 1990, um 10.30 Uhr, bei der Lonza AG in Visp/VS statt. Das Thema der gleichzeitig stattfindenden Frühjahrstagung lautet:

\section{Integrierte Entsorgung in der LONZA}

und ist abgestimmt auf die Fachtagung der Schweizerischen Vereinigung diplomierter Chemiker HTL (SVCT) mit dem Thema:

\section{Abfall-Szene Schweiz:}

\section{Vorsorge, Recycling, Entsorgung}

die am 14. März 1990 bei der Sandoz AG in Basel stattfinden wird.

Die Frühjahrstagung des SChV veranschaulicht mit Vorträgen und einer Besichtigung die praktische Durchführung von Entsorgung und Umweltschutz in der Chemischen Industrie. Reservieren Sie bitte beide Termine.

Der Vorstand SChV

\section{Neue Mitglieder}

Atallah Elias, M.Sc. Environmental Pollution Control (University of Leeds, UK), selbständiger Chemieund Umweltingenieur, Bürglistrasse 22, 8400 Winterthur.

Crevoisier Michel, Dr. phil. nat. (Universität Bern), Marchbachstrasse 11, 4107 Ettingen.

Hilfiker Rolf, Dr. phil. nat. (Universität Basel), Breisacherstrasse 68, 4057 Basel.

Matter Walter, Dr. sci. nat. (ETH Zürich), Zumhofstrasse 76,6010 Kriens.

Müller René, Dipl.Chem., Doktorand (ETH Zürich), Fürschtweg $36 \mathrm{~B}, 8880$ Walenstadt.

Wyden Horst, Chemiker HTL, Fohlenweidstrasse 35,8615 Wermatswil.

\section{Personalia}

\section{Beförderungen in der Industrie}

"Wissenschaftlicher Experte» und «Experte» sind als firmeninterne Titel (Ciba-Geigy, Hoffmann-La Roche) Auszeichnungen für wissenschaftliche bzw. andere Leistungen, deren Bedeutung einer Beförderung in den Direktorenrang entspricht.

\section{LABORATORIEN HAUSMANN AG}

Die Geschäftsleitung Hausmann/Vifor hat zum Wissenschaftlichen Experten ernannt:

Dr. Peter Geisser, Leiter der chemischen und biochemischen Forschung.

\section{Ehrungen}

Jeremy R. Knowles, Prof. für Chemie und Biochemie an der Harvard University, Cambridge, Massachusetts (USA), ist an der ETH Zürich in Anerkennung seiner grundlegenden Beiträge zur Stereochemie mit der Prelog-Medaille 1989 ausgezeichnet worden.

Dieter Seebach, Prof. für Chemie am Laboratorium für Organische Chemie der ETH Zürich, wurde von der Université Montpellier II Sciences et Techniques du Languedoc, Frankreich, der Titel Docteur honoris causa verliehen. Mit der Ehrendoktorurkunde wurde ihm die aus Anlass der 700-Jahr-Feier der Universität Montpellier (1989) geprägte Medaille überreicht.

\section{Ernennung}

Alfons Baiker, Dr., Titularprofessor und Privatdozent am Laboratorium für Technısche Chemie der ETH Zürich, wurde zum ausserordentlichen Professor ernannt.

\section{PSI Minisymposium}

\section{Elektrochemische Energiespeicherung}

\section{Bern, 8. März 1990}

Tagungsort: Universität Bern, Chemische Institutc, Freiestrasse 3, Hörsaal EG 16

\section{Programm}

\subsection{Begrüssung}

$10.20 W . A . M c R a e$, Zürich (früher Fa. Ionics, USA) "Ion Exchange Membranes I"

- brief history of synthetic ion exchange/ion selective membranes - preparation of ion exchange membranes

11.05 Diskussion

11.20 W. A. McRae

"Ion Exchange Membranes II"

- physical-chemical properties important to electrochemical applications

12.05 Diskussion

14.00 G.B. Tanny, Advanced Technology, Gelman Science Inc., USA

«Transport Selective Membranes as Battery Separators"

- separators for $\mathrm{Zn} / \mathrm{MnO}_{2}, \mathrm{Ag} / \mathrm{AgO}$, and $\mathrm{Zn} / \mathrm{HgO}$ batteries

- novel separator for lithium batteries

14.45 Diskussion

15.20 W. Böhnstedt, Grace GmbH, Battery Separator Technical Center, Norderstedt (Hamburg) «Der Einfluss des Separators auf die Antimonvergiftung in zyklisch belasteten Bleiakkumulatoren"

16.05 Diskussion

16.20 Schluss

Information/Kontakt

- Dr. G. Scherer

Paul Scherrer Institut

CH-5232 Villigen PSI

Tel.: (056) 992928 


\section{Frühjahrsversammlung 1990 in Zürich}

Am Freitag, den 16. März dieses Jahres, wird die SCG-Frühjahrsversammlung an der ETH Zürich-Zentrum, Hauptgebäude, Auditorium Maximum, Rämistrasse 101, stattfinden:

\section{Trends in Organic Chemistry}

09.30 Geschäftlicher Teil

Wissenschaftlicher Teil

10.00 J.-M. Lehn (Université Louis Pasteur, Strasbourg):

"Perspektiven der supramolekularen Chemie»

II.00 Pause

11.15 Ehrungen der Schweizerischen Chemischen Gesellschaft:

Verleihung des Werner-Preises und des Paracelsus-Preises 1990

11.30 R. Breslow (Columbia University, New York): "The Chelate Effect: Binding, Catalysis, and Chemotherapy"

12.30 Mittagspause

14.30 J. Rebek, jr. (Massachusetts Institute of Technology):

"Recognition and Catalysis with Model Systems"

15.30 S. L. Schreiber (Harvard University, Cambridge, U.S.A.):

"Molecular Recognition of the Immunophilins" 16.30 Pause

16.50 P.G. Schultz (University of California, Berkeley):

"Catalytic Antibodies"

17.50 Schluss der Versammlung

Information/Kontakt:

- Dr. E. Zass, Sekretär SCC

ETĤ Zürich, Universitätstrasse 16

$\mathrm{CH}-8092$ Zürich

An den beiden vorhergehenden Tagen veranstaltet die Schweizerische Gesellschaft für Kristallographie vom 14.-15. März am gleichen Ort

\section{Chemistry and Structure}

A Symposium in Honour of Professor J.D. Dunitz

mit Vorträgen von

H.-B. Bürgi (Bern): «Reaction Rate and Geometrical Structure»

J. Bernstein (Beer-Sheva): "Polymorphism in Organic Crystals - Utilizing and Understanding the Differences"

J.D. Dunitz (Zürich): «Chemical Aspects of Phase Transitions in Molecular Crystals"

A. Gavezzotti (Milan): «The Crystal Packing of Organic Molecules - Geometry and Forces»

R. Hoffmann (Cornell): «Waiting to be Made»

\section{Frühjahrstagung der}

Polymer-Gruppe der Schweiz (PGS):

\section{Polymer-Forschung und -Entwicklung in der Industrie}

Biel/Bienne, 22. März 1990

Mit dieser Tagung im Hotel Elite setzt die PGS ihren Vortragszyklus über «Industrielle F + E-Tätigkeiten auf dem Polymer-Gebiet in der Schweiz" fort, wobei den in der Schweiz tätigen Firmen die Möglichkeit geboten wird, sich vorzustellen. An der zweiten Tagung

im Rahmen dieses Zyklus werden die Firmen:

- Asea Brown Boveri AG,

- Ciba-Geigy AG,

- Huber \& Suhner AG,

- Isola-Werke AG

über ihr Tätigkeitsgebiet berichten.

Weitere Auskünfte und Anmeldungen:

- Sekretariat der PGS am Institut für Polymere der ETH-Z

Universitätstrasse 6

CH-8092 Zürich

Tel.: (01) 2563058

Mitteilungen des

Schweizerischen

Chemiker-Verbandes (SCV)

\section{Voranzeige: Generalversammlung und Frühjahrstagung '90 des $\mathrm{SChV}$}

Die diesjährige Generalversammlung des SChV findet am 27. April 1990, um 10.30 Uhr, bei der Lonza AG in Visp/VS statt. Das Thema der gleichzeitig stattfindenden Frühjahrstagung lautet:

\section{Integrierte Entsorgung in der LONZA}

und ist abgestimmt auf die Fachtagung der Schweizerischen Vereinigung diplomierter Chemiker HTL (SVCT) mit dem Thema:

\section{Abfall-Szene Schweiz:}

\section{Vorsorge, Recycling, Entsorgung}

die am 14. März 1990 bei der Sandoz AG in Basel stattfinden wird.

Die Frühjahrstagung des SChV veranschaulicht mit Vorträgen und einer Besichtigung die praktische Durchführung von Entsorgung und Umweltschutz in der Chemischen Industrie. Reservieren Sie bitte beide Termine.

Der Vorstand SChV

\section{Neue Mitglieder}

Atallah Elias, M.Sc. Environmental Pollution Control (University of Leeds, UK), selbständiger Chemieund Umweltingenieur, Bürglistrasse 22, 8400 Winterthur.

Crevoisier Michel, Dr. phil. nat. (Universität Bern), Marchbachstrasse 11, 4107 Ettingen.

Hilfiker Rolf, Dr. phil. nat. (Universität Basel), Breisacherstrasse 68, 4057 Basel.

Matter Walter, Dr. sci. nat. (ETH Zürich), Zumhofstrasse 76,6010 Kriens.

Müller René, Dipl.Chem., Doktorand (ETH Zürich), Fürschtweg $36 \mathrm{~B}, 8880$ Walenstadt.

Wyden Horst, Chemiker HTL, Fohlenweidstrasse 35,8615 Wermatswil.

\section{Personalia}

\section{Beförderungen in der Industrie}

"Wissenschaftlicher Experte» und «Experte» sind als firmeninterne Titel (Ciba-Geigy, Hoffmann-La Roche) Auszeichnungen für wissenschaftliche bzw. andere Leistungen, deren Bedeutung einer Beförderung in den Direktorenrang entspricht.

\section{LABORATORIEN HAUSMANN AG}

Die Geschäftsleitung Hausmann/Vifor hat zum Wissenschaftlichen Experten ernannt:

Dr. Peter Geisser, Leiter der chemischen und biochemischen Forschung.

\section{Ehrungen}

Jeremy R. Knowles, Prof. für Chemie und Biochemie an der Harvard University, Cambridge, Massachusetts (USA), ist an der ETH Zürich in Anerkennung seiner grundlegenden Beiträge zur Stereochemie mit der Prelog-Medaille 1989 ausgezeichnet worden.

Dieter Seebach, Prof. für Chemie am Laboratorium für Organische Chemie der ETH Zürich, wurde von der Université Montpellier II Sciences et Techniques du Languedoc, Frankreich, der Titel Docteur honoris causa verliehen. Mit der Ehrendoktorurkunde wurde ihm die aus Anlass der 700-Jahr-Feier der Universität Montpellier (1989) geprägte Medaille überreicht.

\section{Ernennung}

Alfons Baiker, Dr., Titularprofessor und Privatdozent am Laboratorium für Technısche Chemie der ETH Zürich, wurde zum ausserordentlichen Professor ernannt.

\section{PSI Minisymposium}

\section{Elektrochemische Energiespeicherung}

\section{Bern, 8. März 1990}

Tagungsort: Universität Bern, Chemische Institutc, Freiestrasse 3, Hörsaal EG 16

\section{Programm}

\subsection{Begrüssung}

$10.20 W . A . M c R a e$, Zürich (früher Fa. Ionics, USA) "Ion Exchange Membranes I"

- brief history of synthetic ion exchange/ion selective membranes - preparation of ion exchange membranes

11.05 Diskussion

11.20 W. A. McRae

"Ion Exchange Membranes II"

- physical-chemical properties important to electrochemical applications

12.05 Diskussion

14.00 G.B. Tanny, Advanced Technology, Gelman Science Inc., USA

«Transport Selective Membranes as Battery Separators"

- separators for $\mathrm{Zn} / \mathrm{MnO}_{2}, \mathrm{Ag} / \mathrm{AgO}$, and $\mathrm{Zn} / \mathrm{HgO}$ batteries

- novel separator for lithium batteries

14.45 Diskussion

15.20 W. Böhnstedt, Grace GmbH, Battery Separator Technical Center, Norderstedt (Hamburg) «Der Einfluss des Separators auf die Antimonvergiftung in zyklisch belasteten Bleiakkumulatoren"

16.05 Diskussion

16.20 Schluss

Information/Kontakt

- Dr. G. Scherer

Paul Scherrer Institut

CH-5232 Villigen PSI

Tel.: (056) 992928 


\section{Frühjahrsversammlung 1990 in Zürich}

Am Freitag, den 16. März dieses Jahres, wird die SCG-Frühjahrsversammlung an der ETH Zürich-Zentrum, Hauptgebäude, Auditorium Maximum, Rämistrasse 101, stattfinden:

\section{Trends in Organic Chemistry}

09.30 Geschäftlicher Teil

Wissenschaftlicher Teil

10.00 J.-M. Lehn (Université Louis Pasteur, Strasbourg):

"Perspektiven der supramolekularen Chemie»

II.00 Pause

11.15 Ehrungen der Schweizerischen Chemischen Gesellschaft:

Verleihung des Werner-Preises und des Paracelsus-Preises 1990

11.30 R. Breslow (Columbia University, New York): "The Chelate Effect: Binding, Catalysis, and Chemotherapy"

12.30 Mittagspause

14.30 J. Rebek, jr. (Massachusetts Institute of Technology):

"Recognition and Catalysis with Model Systems"

15.30 S. L. Schreiber (Harvard University, Cambridge, U.S.A.):

"Molecular Recognition of the Immunophilins" 16.30 Pause

16.50 P.G. Schultz (University of California, Berkeley):

"Catalytic Antibodies"

17.50 Schluss der Versammlung

Information/Kontakt:

- Dr. E. Zass, Sekretär SCC

ETĤ Zürich, Universitätstrasse 16

$\mathrm{CH}-8092$ Zürich

An den beiden vorhergehenden Tagen veranstaltet die Schweizerische Gesellschaft für Kristallographie vom 14.-15. März am gleichen Ort

\section{Chemistry and Structure}

A Symposium in Honour of Professor J.D. Dunitz

mit Vorträgen von

H.-B. Bürgi (Bern): «Reaction Rate and Geometrical Structure»

J. Bernstein (Beer-Sheva): "Polymorphism in Organic Crystals - Utilizing and Understanding the Differences"

J.D. Dunitz (Zürich): «Chemical Aspects of Phase Transitions in Molecular Crystals"

A. Gavezzotti (Milan): «The Crystal Packing of Organic Molecules - Geometry and Forces»

R. Hoffmann (Cornell): «Waiting to be Made»

\section{Frühjahrstagung der}

Polymer-Gruppe der Schweiz (PGS):

\section{Polymer-Forschung und -Entwicklung in der Industrie}

Biel/Bienne, 22. März 1990

Mit dieser Tagung im Hotel Elite setzt die PGS ihren Vortragszyklus über «Industrielle F + E-Tätigkeiten auf dem Polymer-Gebiet in der Schweiz" fort, wobei den in der Schweiz tätigen Firmen die Möglichkeit geboten wird, sich vorzustellen. An der zweiten Tagung

im Rahmen dieses Zyklus werden die Firmen:

- Asea Brown Boveri AG,

- Ciba-Geigy AG,

- Huber \& Suhner AG,

- Isola-Werke AG

über ihr Tätigkeitsgebiet berichten.

Weitere Auskünfte und Anmeldungen:

- Sekretariat der PGS am Institut für Polymere der ETH-Z

Universitätstrasse 6

CH-8092 Zürich

Tel.: (01) 2563058

Mitteilungen des

Schweizerischen

Chemiker-Verbandes (SCV)

\section{Voranzeige: Generalversammlung und Frühjahrstagung '90 des $\mathrm{SChV}$}

Die diesjährige Generalversammlung des SChV findet am 27. April 1990, um 10.30 Uhr, bei der Lonza AG in Visp/VS statt. Das Thema der gleichzeitig stattfindenden Frühjahrstagung lautet:

\section{Integrierte Entsorgung in der LONZA}

und ist abgestimmt auf die Fachtagung der Schweizerischen Vereinigung diplomierter Chemiker HTL (SVCT) mit dem Thema:

\section{Abfall-Szene Schweiz:}

\section{Vorsorge, Recycling, Entsorgung}

die am 14. März 1990 bei der Sandoz AG in Basel stattfinden wird.

Die Frühjahrstagung des SChV veranschaulicht mit Vorträgen und einer Besichtigung die praktische Durchführung von Entsorgung und Umweltschutz in der Chemischen Industrie. Reservieren Sie bitte beide Termine.

Der Vorstand SChV

\section{Neue Mitglieder}

Atallah Elias, M.Sc. Environmental Pollution Control (University of Leeds, UK), selbständiger Chemieund Umweltingenieur, Bürglistrasse 22, 8400 Winterthur.

Crevoisier Michel, Dr. phil. nat. (Universität Bern), Marchbachstrasse 11, 4107 Ettingen.

Hilfiker Rolf, Dr. phil. nat. (Universität Basel), Breisacherstrasse 68, 4057 Basel.

Matter Walter, Dr. sci. nat. (ETH Zürich), Zumhofstrasse 76,6010 Kriens.

Müller René, Dipl.Chem., Doktorand (ETH Zürich), Fürschtweg $36 \mathrm{~B}, 8880$ Walenstadt.

Wyden Horst, Chemiker HTL, Fohlenweidstrasse 35,8615 Wermatswil.

\section{Personalia}

\section{Beförderungen in der Industrie}

"Wissenschaftlicher Experte» und «Experte» sind als firmeninterne Titel (Ciba-Geigy, Hoffmann-La Roche) Auszeichnungen für wissenschaftliche bzw. andere Leistungen, deren Bedeutung einer Beförderung in den Direktorenrang entspricht.

\section{LABORATORIEN HAUSMANN AG}

Die Geschäftsleitung Hausmann/Vifor hat zum Wissenschaftlichen Experten ernannt:

Dr. Peter Geisser, Leiter der chemischen und biochemischen Forschung.

\section{Ehrungen}

Jeremy R. Knowles, Prof. für Chemie und Biochemie an der Harvard University, Cambridge, Massachusetts (USA), ist an der ETH Zürich in Anerkennung seiner grundlegenden Beiträge zur Stereochemie mit der Prelog-Medaille 1989 ausgezeichnet worden.

Dieter Seebach, Prof. für Chemie am Laboratorium für Organische Chemie der ETH Zürich, wurde von der Université Montpellier II Sciences et Techniques du Languedoc, Frankreich, der Titel Docteur honoris causa verliehen. Mit der Ehrendoktorurkunde wurde ihm die aus Anlass der 700-Jahr-Feier der Universität Montpellier (1989) geprägte Medaille überreicht.

\section{Ernennung}

Alfons Baiker, Dr., Titularprofessor und Privatdozent am Laboratorium für Technısche Chemie der ETH Zürich, wurde zum ausserordentlichen Professor ernannt.

\section{PSI Minisymposium}

\section{Elektrochemische Energiespeicherung}

\section{Bern, 8. März 1990}

Tagungsort: Universität Bern, Chemische Institutc, Freiestrasse 3, Hörsaal EG 16

\section{Programm}

\subsection{Begrüssung}

$10.20 W . A . M c R a e$, Zürich (früher Fa. Ionics, USA) "Ion Exchange Membranes I"

- brief history of synthetic ion exchange/ion selective membranes - preparation of ion exchange membranes

11.05 Diskussion

11.20 W. A. McRae

"Ion Exchange Membranes II"

- physical-chemical properties important to electrochemical applications

12.05 Diskussion

14.00 G.B. Tanny, Advanced Technology, Gelman Science Inc., USA

«Transport Selective Membranes as Battery Separators"

- separators for $\mathrm{Zn} / \mathrm{MnO}_{2}, \mathrm{Ag} / \mathrm{AgO}$, and $\mathrm{Zn} / \mathrm{HgO}$ batteries

- novel separator for lithium batteries

14.45 Diskussion

15.20 W. Böhnstedt, Grace GmbH, Battery Separator Technical Center, Norderstedt (Hamburg) «Der Einfluss des Separators auf die Antimonvergiftung in zyklisch belasteten Bleiakkumulatoren"

16.05 Diskussion

16.20 Schluss

Information/Kontakt

- Dr. G. Scherer

Paul Scherrer Institut

CH-5232 Villigen PSI

Tel.: (056) 992928 